
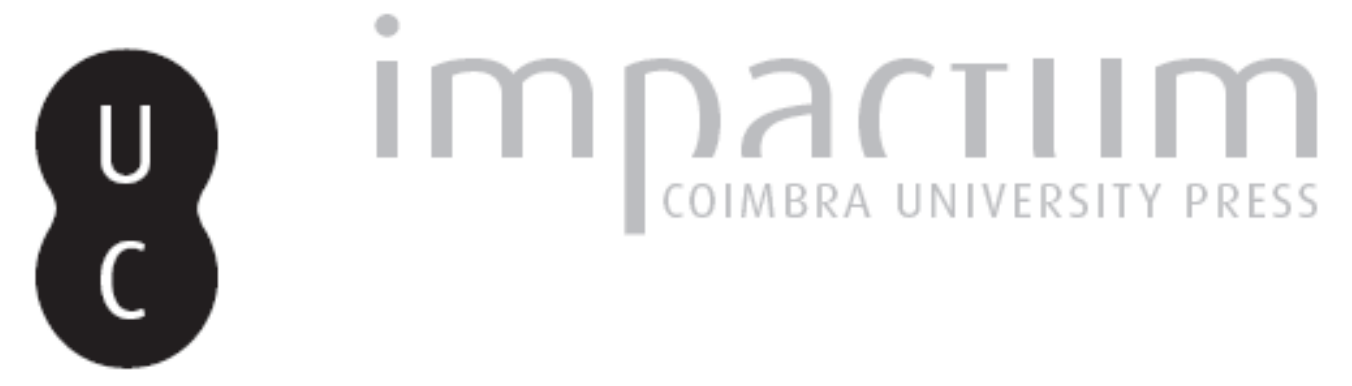

O poder intelectual dos médicos (finais do século XIX - inícios do século XX)

Autor(es): $\quad$ Garnel, Maria Rita Lino

Publicado por: Imprensa da Universidade de Coimbra

URL persistente:

URI:http://hdl.handle.net/10316.2/43720

DOI:

DOI:https://doi.org/10.14195/2183-8925_24_7

Accessed : $\quad$ 26-Apr-2023 14:43:48

A navegação consulta e descarregamento dos títulos inseridos nas Bibliotecas Digitais UC Digitalis, UC Pombalina e UC Impactum, pressupõem a aceitação plena e sem reservas dos Termos e Condições de Uso destas Bibliotecas Digitais, disponíveis em https://digitalis.uc.pt/pt-pt/termos.

Conforme exposto nos referidos Termos e Condições de Uso, o descarregamento de títulos de acesso restrito requer uma licença válida de autorização devendo o utilizador aceder ao(s) documento(s) a partir de um endereço de IP da instituição detentora da supramencionada licença.

Ao utilizador é apenas permitido o descarregamento para uso pessoal, pelo que o emprego do(s) título(s) descarregado(s) para outro fim, designadamente comercial, carece de autorização do respetivo autor ou editor da obra.

Na medida em que todas as obras da UC Digitalis se encontram protegidas pelo Código do Direito de Autor e Direitos Conexos e demais legislação aplicável, toda a cópia, parcial ou total, deste documento, nos casos em que é legalmente admitida, deverá conter ou fazer-se acompanhar por este aviso. 

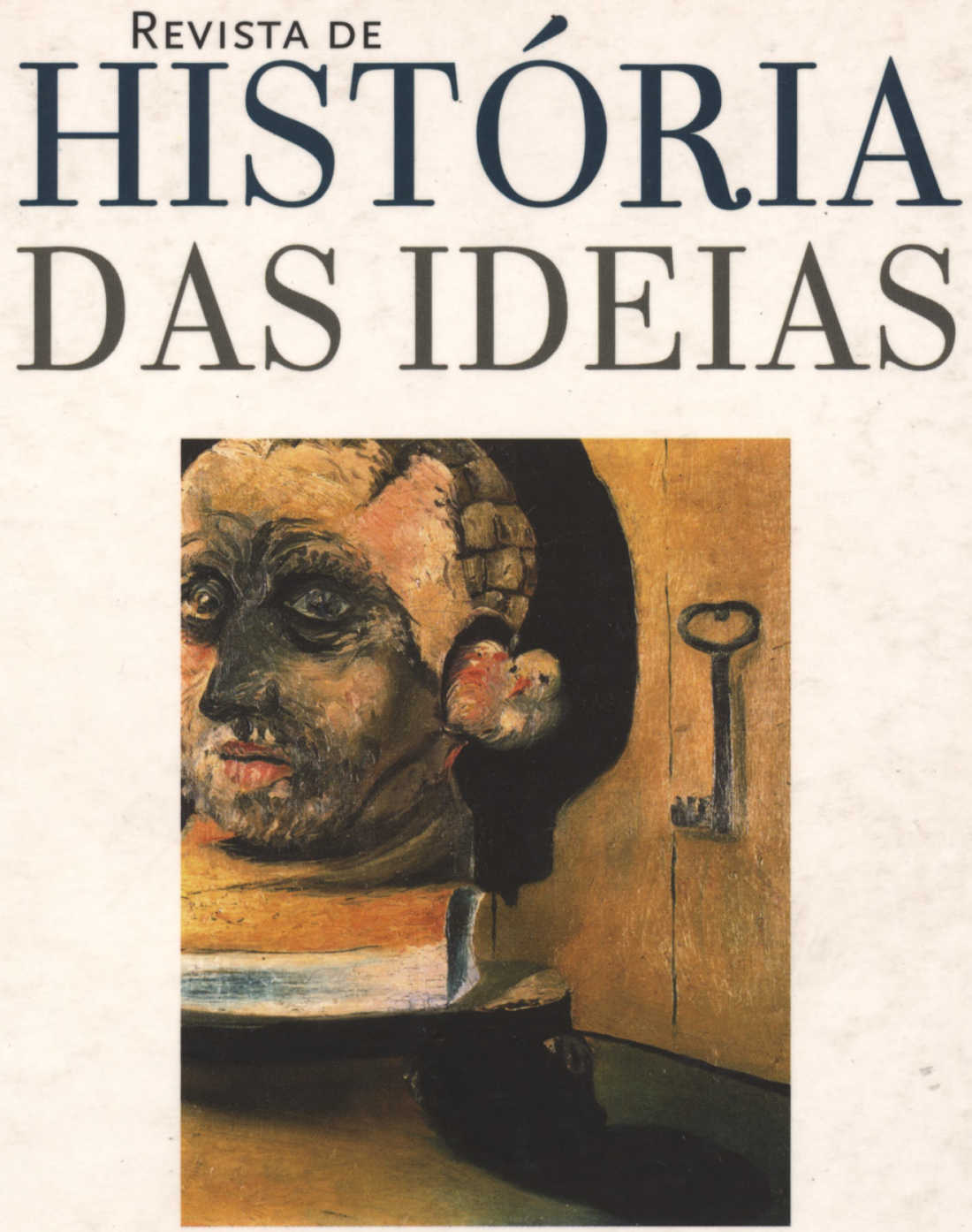

OS INTELECTUAIS E OS PODERES

Volume 24, 2003

INSTITUTO DE HISTÓRIA E TEORIA DAS IDEIAS

Faculdade de Letras da Universidade de Coimbra 


\title{
O PODER INTELECTUAL DOS MÉDICOS Finais do século XIX - inícios do século XX
}

\begin{abstract}
"Ao médico cabe por direito tradicional o primado entre os cérebros, preiteado desde a Odisseia de Homero até à filosofia de Comte - Medicus vero unusquisque peritus omnes homines ( $\mathrm{Na}$ verdade cada médico é perito acerca de todos os homens")(1).
\end{abstract}

\section{Introdução}

Em 1884, numa conferência proferida no Porto, Ricardo Jorge afirmava que "grassa em demasia o preconceito de que o campo médico é uma especialidade estreita e reservada; transpô-lo, em nome da própria ciência afigura-se talvez um atentado. É forçoso e legítimo combater de frente esse prejuízo ignaro, e assegurar esse papel supremo que à nossa ciência cabe na direç̧ão mental e social" (2). Com isto reivindicava o reconhecimento do papel tutelar que o médico devia exercer nas sociedades modernas, isto é, nas sociedades que, afastados os preconceitos religiosos

\footnotetext{
* Bolseira de doutoramento da FCT.

(1) Ricardo Jorge, "O médico penitente", A Medicina Contemporânea. Hebdomadario Portuguez de Sciencias Medicas, Anno XXXI, n 49, 7-XII-1913, p. 390.

(2) Idem, Hygiene social applicada à nação portugueza. Conferências feitas no Porto, Porto, Livraria Civilisação de Eduardo Costa Santos-Editor, 1885, pp. 40-41.
} 
e/ou metafísicos, se quereriam regidas pela ciência, religião do futuro tal como Comte profetizara.

$\mathrm{Na}$ verdade, se houve grupo sócio-profissional que conseguiu, ao longo de Oitocentos, de forma consistente e continuada, impor o seu saber como princípio de conhecimento, de orientação e de transformação da sociedade, esse grupo foi o dos médicos. A sua crescente afirmação mede-se pela eficácia com que estruturaram as práticas, as mais quotidianas, moldaram os corpos e regeram os comportamentos, criando, simultaneamente, a ilusão de deterem um novo poder salvífico.

Este artigo pretende examinar algumas das ideias e a força de um grupo que conseguiu impor, sem violência, o conjunto das suas definições do mundo, fazendo-as aceitar não só como as mais adequadas à realização da felicidade colectiva, mas também como as únicas capazes de realizar a harmonia social. Não quer isto dizer que o processo tenha sido totalmente pacífico. Se na estratégia de convencimento utilizada pelos médicos, o apoio e a anuência do poder político, que soube absorver na administração pública grande número destes profissionais liberais, foi passo decisivo, a luta, intelectual embora, com outros saberes/poderes foi explicitamente assumida em todas as frentes.

Em primeiro lugar, com os antigos detentores dos instrumentos de produção simbólica - os padres. Há todos os motivos para perceber o médico, tal como ele nos aparece na sociedade do século XIX e inícios do século $\mathrm{XX}$ - âmbito cronológico deste artigo - como um novo clerc. É que ele emerge como o proprietário de um saber especializado, que é um poder de evitar, ou pelo menos atenuar, o sofrimento, um poder/ /saber sobre a vida, capaz de afastar a morte. De realizar a salvação nesta vida, agora sacralizada. A ciência médica, usufruindo do geral prestígio da ciência, impôs-se como um saber secularizado, por vezes de combate anticlerical, mas que, laica e supletivamente soube sacralizar o seu conhecimento, a sua linguagem e a sua acção.

Ao longo de Oitocentos, nesta luta pelo poder simbólico, os médicos também tiveram de se defrontar com a posição de relevo ganha pela literatura (e pelo literato) na liderança da opinião pública esclarecida do país. É que o prestígio e o poder da palavra, escrita e/ou falada, faziam emergir o escritor e, em especial, o poeta como o encarnador daquilo que se começava a chamar o espírito do tempo ou o espírito da nação. Mediadores da memória e da história, os poetas pareciam ser capazes de transcender o tempo e a morte. Os médicos, por seu lado, afirmavam-se 
como cientistas, capazes de prometer o adiamento (crescente) do desfecho inevitável da vida. E se o prestígio da ciência e, em particular, da medicina induziram em alguns poetas e/ou romancistas uma atitude cientificista - veja-se o caso de Zola em França ou de Abel Botelho em Portugal -, o médico começou igualmente a pronunciar-se, no seguimento de Max $\operatorname{Nordau}^{(3)}$, sobre a obra de $\operatorname{arte}^{(4)}$, patologizando mesmo algumas correntes estéticas que não se compaginavam com o optimismo gnosiológico e histórico que inferiam do seu próprio saber.

Luta da medicina, também, contra o saber do Direito e o poder dos seus intérpretes. Combate pelo poder de enunciação, isto é, pela capacidade de fazer ver o mundo e de o transformar. Talvez neste combate a vitória visível tenha sido dos legistas; mas alcançaram-na com crescente incorporação da visão médica da sociedade.

Por outro lado, compreender o poder do saber médico significa, ainda, ter em conta a transformação da imagem do corpo e o deslocamento das atenções da doença para a saúde. Quer isto dizer que, a partir dos meados do século XVIII, o progressivo conhecimento da anatomia e, já no século XIX, o avanço do conhecimento fisiológico deram lugar a uma profunda revolução. $\mathrm{O}$ corpo humano começou a ser visto como portador de resistências insuspeitadas ${ }^{(5)}$, mas também vulnerável às condições mesológicas ${ }^{(6)}$. Conhecer o homem, saudável ou doente, e explicar o seu comportamento, normal ou patológico - ambição totalizadora da medicina -, decorre entre estes dois pólos explicativos que parecem excluir-se. Começava, pois a desenhar-se uma fractura entre natureza e cultura, ainda hoje por resolver ${ }^{(7)}$, e que deu lugar a um duro combate

(3) Max Nordau, Dégénerescence, Paris, Félix Alcan, 1899.

(4) Veja-se, por exemplo, Miguel Bombarda, "Duse", A Medicina Contemporanea..., XVI Anno, n 18, 1-V-1898, pp. 40-41; idem, "Casa de Boneca", ibidem, XVII Anno, no 14, 2-IV-1899, pp. 109-110.

(5) Georges Vigarello, Histoire des pratiques de santé. Le sain et le malsain depuis le Moyen Âge, Paris, Seuil, 1999, p. 148.

(6) Patrick Bourdelais, "Les logiques du dévéloppement de l'hygiène publique", in Les Hygiènistes. Enjeux, modèles et pratiques (XVIII ème-XX ème siècles), Paris, Éditions Belin, 2001, p. 12.

(7) Anne Fausto-Sterling, Sexing the body. Gender politics and the construction of sexuality, New York, Basic Books, 2000, em especial o capítulo 8, "The rodent's tale", pp. 195-232. 
entre os que perfilharam o determinismo naturalista e aqueles que, mais optimistas, entendiam que o meio, geográfico, étnico ou social, condicionava, mais ou menos poderosamente, os comportamentos individuais e/ou colectivos. Considerar o homem determinado pela sua natureza, se, por um lado, restringia a responsabilidade individual, por outro, colocava o médico como o único possuidor de conhecimentos capazes de interpretar e, por isso, de prever e controlar os indícios perturbadores da ordem social. Atender aos condicionalismos do meio significava, porventura, prescindir de um poder total; permitia, porém, o alargamento do olhar médico a domínios que até então lhe escapavam. Ora, a partir dos finais de Setecentos, o saber médico, antes de curar, quis prevenir o aparecimento da doença e/ou evitar a eclosão e a propagação das epidemias, problema cada vez mais candente num tempo de crescimento demográfico sem precedentes e de aumento e concentração populacional nos meios urbanos.

Este desenvolvimento implicou o olhar, o tratamento e a cura do corpo individual, em termos de uma crescente e rigorosa disciplina (recorde-se o sentido do termo polícia na transição do Antigo Regime, e as muitas atribuições médicas deste corpo de vigilantes); mas também visou constranger todo o corpo social ao seu poder, em nome de um novo objectivo: a saúde pública ${ }^{(8)}$. Este alargamento permitiu que o médico se assumisse, ao longo do século XIX, como o detentor exclusivo de uma certa tecnologia de poder capaz de socializar o corpo em função da sua força produtiva ${ }^{(9)}$. Quer isto dizer, e como Ricardo Jorge em 1885 já compreendera, se o seu âmbito de aplicação não se esgotava no conhecimento e terapêutica individual, o seu poder devia estender-se à regulamentarização dos comportamentos colectivos e ao reordenamento dos tempos e dos espaços - públicos ou privados; ou dito de outra forma, o saber da medicina, ao longo de Oitocentos, foi peça fundamental de uma biopolítica - para usar a expressão consagrada por Michel Foucault -, isto é, de um saber/poder sobre a população, que ajudou a tornar mais visível e, por isso, controlável. A saúde passou a ser um objectivo

(8) Sobre a "polícia médica", para o Portugal da primeira metade de Oitocentos, veja-se, Ana Leonor Pereira e João Rui Pita, "Liturgia higienista no século XIX", Revista de História das Ideias, vol. 15, 1993, pp. 437-559, em especial as pp. 462-492.

(9) Michel Foucault, "Nacimiento de la medicina social", in Estrategias de poder. Obras Essenciales, vol. II, Barcelona, Paidós, 1999, pp. 365-366. 
político ${ }^{(10)}$, só possível de ser alcançado com o concurso e a orientação do médico.

Tendo em conta o que ficou dito, compreender-se-á a estrutura deste trabalho. Para se falar do poder intelectual dos médicos, ter-se-á de falar do poder dos médicos, da consciência que de si tiveram e da capacidade que revelaram para convencer os outros da superioridade do seu saber. Assim, examinar-se-ão algumas das estratégias que utilizaram para consolidar o seu estatuto e o seu papel no seio das elites intelectuais; quer isto dizer que terá de se olhar para as redes de sociabilidade em construção, para a sua implantação em lugares de poder, bem como para a sua capacidade de organização enquanto grupo profissional, que se afirma merecedor de um crédito social particular; em seguida, expor-se-ão algumas das ideias que permitem caracterizar as pretensões totalizadoras do seu saber, ideias essas que nortearam a intervenção pública do médico e em nome das quais se reivindicaram (e, por vezes, se conseguiram impor) medidas que visavam o reordenamento da sociedade.

\section{A consolidação do poder médico}

Ao longo do século XIX, os médicos lutarão para se imporem como uma profissão de valor e estatuto social privilegiado e reconhecido. A regulamentação profissional é uma das formas pelas quais se pode medir a força de um grupo. Desiderato que depende, simultaneamente, da capacidade de mobilizar os seus praticantes e de convencer os poderes e, também, sectores importantes da opinião pública da importância crucial do seu saber particular.

\section{$A$ identidade profissional}

Extintas as corporações com a revolução liberal, será no seio do próprio Estado que as profissões modernas se constituem ${ }^{(11)}$. Significa isto, que a

(10) Idem, "La politica de salud en el siglo XVIII", in ibidem, pp. 327-342.

(11) Edmundo Campos Coelho, As Profissões Imperiais. Medicina, engenharia e advocacia no Rio de Janeiro, Rio de Janeiro, Ed. Record, 1999, p. 32. 
medicina, como outras profissões - a polícia, por exemplo ${ }^{(12)}-$, não devem ser consideradas como algo de exterior ao poder público, mas sim entendidas como um dos factores de governabilidade que permitiu a construção do Estado moderno. Tanto mais que a condição de peritos, isto é, de portadores de um saber e de uma competência técnica, cujos fundamentos se afirmam ser científicos, lhes possibilitou estar "intimamente envolvidos na geração de definições oficiais da realidade"(13). Aceites as definições, o Estado poderia actuar, reconhecendo, do mesmo passo, a competência e o valor social dos médicos.

A construção de uma identidade profissional ainda exigia, na década de 80, o esclarecimento prévio de uma questão. Assim, aos que insistiam ser a medicina um sacerdócio, o redactor da Medicina Contemporânea não tinha dúvidas em esclarecer que "se com semelhante definição quer impor-se a gratuidade, completa e absoluta, às funções do clínico, será lícito perguntar qual a subvenção do Estado, do município, da paróquia, que anda adscrita a essa clerezia de nova espécie"(14). A questão era pertinente, pois o médico, como outrora o clero, começava a ocupar um lugar destacado na sociedade: como o padre, também ele era o portador exclusivo de um saber que, se tinha o seu ponto de partida na cura do corpo, foi-se estendendo, ao longo do século XIX, ao tratamento do espírito (desenvolvimento da psiquiatria). Mas, dado que a maioria dos médicos, de facto, não dependia financeiramente senão de si próprios, podia responder-se tranquilamente que o "exercício da medicina [...] é o de uma profissão; o médico prestando os seus serviços a quem lhos paga, recebendo os seus honorários e disso vivendo, representando para o estado como qualquer industrial, exerce efectivamente uma profissão"(15). Deste modo, os médicos afirmavam-se como profissionais liberais, isto é, trabalhando em completa independência, esquecendo, retoricamente, os muitos laços que se teciam entre medicina e instituições públicas (ensino, hospitais, autarquias). E a legislação (como as leis sanitárias de 1900) lembrava que "todo o médico é considerado funcionário técnico

${ }^{(12)}$ Hélène L'Heuillet, Basse politique, haute police. Une approche historique et philosophique de la police, Paris, Fayard, 2001, p. 11.

(13) Idem, ibidem, p. 57.

(14) A Medicina Contemporanea..., I Anno, $\mathrm{n}^{\circ}$ 8, 25-XI-1883, p. 60.

(15) Ibidem, I Anno, n² 22, 3-VI-1883, p. 173. 
de saúde para o efeito das obrigações que lhe incumbem acerca da participação dos casos de moléstia contagiosa, epidémica ou suspeita e do concurso que deve prestar, quando lho seja requisitado pela autoridade sanitária"(16).

Esta definição do médico como técnico de saúde não surpreende, já que é o Estado quem normaliza, garante e certifica a competência profissional. E será em torno das Escolas de Medicina que uma primeira mobilização dos médicos se conseguirá. Entende-se que só a posse de um diploma asseguraria uma capacidade específica, "dependente da especialização de estudos e conhecimentos, que só pode possuir quem os foi buscar nas escolas e nos seus anfiteatros, nos seus museus, nas suas enfermarias" (17), mas independente de quaisquer posteriores demonstrações práticas de saber. E mais, a posse de um diploma simbolizava, igualmente, a superioridade intelectual da medicina, prática que não se podia confundir com os ofícios mecânicos ou comerciais ${ }^{(18)}$. Daí a importância das polémicas travadas em torno do ensino médico, da sua qualidade e/ou das condições do exercício da ocupação médica, ou o esforço para demarcar o profissional habilitado por diploma concedido por escolas portuguesas, daqueles que, não o possuindo, exerciam artes de curar, com grave prejuízo para a saúde pública, para a bolsa dos enfermos e, do mesmo passo, afectavam o monopólio do mercado da medicina.

Os outros praticantes, que ofereciam métodos alternativos de tratamento ou curas milagrosas - definidos como charlatães -, serão objecto de denúncia continuada, tanto mais que o Código Penal estipulava ser passível de pena de prisão o exercício da medicina sem título ${ }^{(19)}$. A insistência dos médicos, neste domínio, demonstra alguma incapacidade do Estado que, ainda em 1912, se dizia incapaz de fazer cumprir as leis ${ }^{(20)}$; e mostra, igualmente, as dificuldades dos facultativos para assegurarem a exclusividade profissional numa sociedade em que a invocação da ciência e a posse do diploma ainda não bastavam. É que largos estratos

(16) Ibidem, XVIII Anno, n 3, 21-I-1900, p. 21.

(17) Ibidem, I Anno, n 22, 3-VI-1883, p. 173.

(18) Ibidem, I Anno, $n^{\circ} 41,14-X-1883$, p. 327.

(19) Ibidem, I Anno, n 9, 4-III-1883, p. 69.

(20) "Variedades. Exercício illegal da medicina", ibidem, XXX Anno, $\mathrm{n}^{\circ} 20$, 19-V-1912, p. 85. 
da população portuguesa pareciam mais confiantes em métodos tradicionais e mais próximos, não se esquivando de recorrer à intercessão divina quando medicamentos secretos e xaropes milagrosos falhavam ${ }^{(21)}$.

Por sua vez, as objecções à concorrência de médicos estrangeiros podem ser lidas não só como tentativas de controlo de um mercado, mas também como forma de mobilização profissional dos médicos portugueses. De facto, sem o diploma concedido pelas escolas portuguesas, os médicos de outras nacionalidades não poderiam exercer em Portugal. Por isso, a polémica estalou quando, em 1883, se colocou a hipótese de celebrar um acordo com a Espanha, que eximiria os médicos espanhóis do processo de habilitação(22).

A valorização do diploma exigia, logicamente, uma atenção vigilante à qualidade do ensino. $E$, num século em que a ciência e, em particular, a medicina, se queriam experimentais, as críticas "à situação desoladora do nosso ensino médico" queriam sobretudo significar ausência de "laboratórios, pessoal apropriado, colecções, clínicas, dotações, ordenados"(23). Daí que a existência de três escolas de Medicina (Escolas Médico-Cirúrgica de Lisboa e Porto e Faculdade de Medicina de Coimbra), num país de dimensões e rendimentos reduzidos, aparecesse como um esbanjamento de recursos. Ao discutirem os projectos de reestruturação do ensino superior, os médicos de Lisboa, nas páginas da Medicina Contemporânea, sugerem a possibilidade de extinção da Faculdade de Medicina. Entre os argumentos invocados, contavam-se, também, o número diminuto de alunos que frequentavam as escolas médicas $\mathrm{e}$ comparava-se Portugal com a Alemanha - o país cientificamente mais adiantado-que possuiria uma relação médico/habitante muito inferior à do nosso país, ainda que se admitisse que as estatísticas para Portugal eram, neste domínio, inexistentes. A comissão que estudou a reestruturação do ensino médico terá Ricardo Jorge como representante da Escola do Porto que, também ele, propõe a extinção da escola de Coimbra ${ }^{(24)}$.

(21) Almeida Garrett, "A crise profissional", Vida Medica e Scientifica. Revista mensal de sciencias medicas e para-medicas, $1^{\circ}$ Ano, $\mathrm{n}^{\circ} 2$, Fevereiro 1914, p. 57.

(22) A Medicina Contemporanea..., I Anno, $\mathrm{n}^{\circ} 6$, 11-II-1883, p. 45.

(23) Ibidem, III Anno, $\mathrm{n}^{\circ}$ 6, 8-II-1885, p. 41.

(24) Ibidem, III Anno, no 42, 18-X-1885, pp. 333-340 e n ${ }^{\circ} 46,15-X I-1885$, pp. 365-366. 
As reaç̧ões indignadas da Faculdade não se fizeram esperar, e mesmo as palavras contemporizadoras da revista médica de Lisboa, que sublinhava que o seu desejo não era ver extinta a Faculdade, antes se propunha a extinção dos três estabelecimentos e a criação de unicamente dois, "dependentes ou independentes da universidade"(25), não convenceram. Os médicos da Faculdade estavam certos de que, no momento da criação desses tais dois estabelecimentos, a proximidade ao poder, geográfica e social, certamente pesaria a favor da sua localização nos dois centros mais importantes e populosos do país.

Uma das queixas mais frequentes, que sublinhava a deficiência do ensino médico, dizia respeito à insuficente especialização disciplinar. O desdobramento de cadeiras, em particular a autonomia da Medicina Legal, são reivindicadas insistentemente. Criada em 1836, a cadeira de Medicina Legal e Higiene na Faculdade de Coimbra, em Lisboa, só em 1864, ela se desligara da clínica médica; ainda assim, em finais do século XIX, o ensino conjunto da Higiene e da Medicina Legal revelava-se anacrónico. O desenvolvimento das preocupações higienistas e o alargamento do seu âmbito exigiam a criação de uma cadeira própria, sob a responsabilidade de um perito em assuntos de medicina legal, competência que se desejava adquirida com aulas práticas; o que não se compadecia com aquela concentração. Desde os inícios da década de 1880 que, na Sociedade das Ciências Médicas, nas revistas da especialidade e no Parlamento, se moveram esforços no sentido de separar o ensino da Medicina Legal do da Higiene Pública ${ }^{(26)}$. Tal só será conseguido em 1899, ano em que o trabalho de Ricardo Jorge, na contenção do surto de peste bubónica no Porto, convenceu definitivamente os poderes públicos da necessidade de se promover uma reorganização sanitária do país e reformular os serviços médico-legais, e por isso, de autonomizar o ensino dessas matérias ${ }^{(27)}$.

\footnotetext{
(25) Ibidem, III Anno, $\mathrm{n}^{\circ}$ 6, 8-II-1885, p. 42.

(26) Ibidem, III Anno, n 6, 11-II-1883.

(27) Ibidem, XVII Anno, n 9, 26-II-1899, p. 69.
} 
A institucionalização da medicina legal e da higiene

As reivindicações em torno do exercício da medicina legal eram antigas, mas a sua argumentação científica tinha também um outro objectivo: conquistar poderes junto do poder judicial. Desde a fundação da Medicina Contemporânea que os artigos se sucediam insurgindo-se contra as condições do exercício dadas aos peritos e a pouca audiência da moderna antropologia criminal junto dos juízes e outros magistrados. Para o redactor da revista, "os serviços médico-legais como eles têm existido e ainda agora se fazem entre nós, inevitavelmente levam a esta singela consequência: - que não há as garantias bastantes para que um inocente seja salvo de uma condenação", concluindo que melhor fora não haver organização nenhuma, o "que do ponto de vista do inocente acusado, é seguramente menos nociva"(28). Assim, em 1900, é saudada como um progresso substancial a divisão do território nacional em três circunscrições médico-legais e a criação de três morgues e dos conselhos médico-legais, bem como a publicação dos questionários e regulamentos que deveriam servir de guia aos peritos nos exames médico-legais; o que demonstra a atenção crescente com que o Estado ia escutando as reivindicações médicas e se tornava cada vez mais sensível aos desenvolvimentos da antropologia criminal, mas também indica a sua intenção normalizadora e de controlo dos médicos.

As polémicas com outros saberes são, como se sabe, um dos sintomas da força de um grupo profissional. Como Edmundo Campos Coelho lembra, o conflito por jurisdições encontra-se no cerne dos processos de profissionalização; e, para o que nos interessa, o conflito entre medicina e direito, mas também entre medicina e polícia, medicina e farmácia, engenharia ou arquitectura e urbanismo são elementos fundamentais na compreensão do poder médico. Como o mesmo autor aponta, se se pode "traduzir o conflito de jurisdição em termos de competição pela propriedade do problema e pela responsabilidade por sua solução"(29), não é menos verdade que quem reclama a propriedade do problema nem sempre deseja a responsabilidade pela sua solução. Foi muitas vezes o caso dos médicos, que insistentemente reivindicaram a sua presença,

\footnotetext{
(28) Ibidem, I Anno, n 2, 14-I-1883, p. 9.

(29) Edmundo Campos Coelho, ob. cit., p. 65.
} 
mas enquanto peritos-consultores, nas mais variadas instâncias de decisão; isto é, desde a apreciação da salubridade dos edifícios ${ }^{(30)}$, que só eles poderiam cabalmente ajuizar, até à sua particular apetência para se tornarem peritos policiais ${ }^{(31)}$.

Mais duro e longo, porém, foi o combate pela afirmação da capacidade pericial do médico em tribunal, sobretudo nos casos que julgavam a imputabilidade ou inimputabilidade de um réu. Recorde-se, a este propósito, o caso Calmon (1900-1901): no processo de interdição movido pelo cônsul brasileiro, no Porto, José Calmon a sua filha Rosa, três médicos nomeados pelo tribunal declararam-se incompetentes para efectuarem o exame mental à arguida. $\mathrm{O}$ juiz argumentou que a única capacidade legalmente exigível era a de serem facultativos ${ }^{(32)}$. Quer isto dizer, que nos inícios do século $X X$, os tribunais já aceitavam a necessidade de recorrer à opinião médica em casos desta natureza, mas entendiam que peritos eram todos aqueles que possuíssem um diploma em Medicina. Os médicos, por seu lado, quereriam que a condição de perito só fosse reconhecida a quem, além da licenciatura, tivesse habilitação especial. Ainda em 1922, o director do Instituto de Medicina Legal era obrigado a lembrar que, desde 1901, um Acórdão da Relação do Porto estabelecera que "é elemento importante para a decisão de questões desta natureza as consultas ou pareceres de médicos que sejam notáveis pela sua autoridade científica, pela sua respeitabilidade e por estarem de acordo com as noções da ciência"(33).

Um bom sintoma do aumento da sua credibilidade pericial foi o início da realização dos exames médico-legais das vítimas em edifício próprio e por pessoal especializado. Na verdade, até 1912, qualquer médico podia

(30) António de Azevedo, "A proposito da lei sobre casas económicas", A Medicina Contemporanea..., Anno XXXII, n² 25, 21-VI-1914, p. 202.

${ }^{(31)}$ Fernando de Almeida Ribeiro, "O curso de Policia Scientifica da Faculdade de Medicina de Coimbra", Movimento Medico. Revista quinzenal de medicina e cirurgia, VIII Anno, nº 9, 1-V-1912, p. 132.

(32) Bernardo Lucas, Aspecto jurídico do Caso Calmon, Porto, Typ. A vapor de Arthur de Souza \& Irmão, 1901.

${ }^{(33)}$ Azevedo Neves, "O caso Ferreira Monteiro, consulta do advogado, pareceres dos professores Júlio de Matos, Sobral Cid e Azevedo Neves, e a resposta do prof. Azevedo Neves à alegação da ré", Archivos do Instituto de Medicina Legal de Lisboa, série B, $5^{\circ}$ volume, I parte, 1922, pp. 40-41. 
ser chamado ao tribunal para proceder a estes exames ${ }^{(34)}$; mas, a partir desta data, na cidade de Lisboa, os exames passavam a realizar-se na Morgue de Lisboa (o Instituto de Medicina Legal de Lisboa só terá existência oficial em 1917). Grande vitória para a afirmação da disciplina, que consegue impor os seus praticantes como peritos e, dentro deste grupo de especialistas, estabelecer uma hierarquia, cujo topo é inquestionavelmente formado pelo perito alienista. Vitória, também, das técnicas de observação médica do corpo que, do exame dos vestígios conduzia à prova, confirmando-se, assim, como produtora e enunciadora de juízos verdadeiros ${ }^{(35)}$.

Seja como for, o conflito entre medicina e direito, que se prolongará pela I República, é perspectivado pelos médicos em termos da Ciência contra a Metafísica, sendo esta comummente apresentada como um incompreensível resquício de uma etapa anterior do desenvolvimento e do progresso intelectual da humanidade.

A criação da especialidade de médico sanitário (curso que deveria ser feito no Instituto Central de Higiene, também criado em 1900, em Lisboa), suscitará outra polémica com Coimbra. Ele foi aberto aos licenciados em Medicina e era de frequência obrigatória para todos os que, nos distritos ou autarquias, desejassem concorrer às sub-delegacias de saúde. Os alunos da Universidade contestaram, de imediato, a medida ${ }^{(36)}$. E, à proposta do lente de Coimbra, Serras e Silva, para que fosse concedido o direito de fazer a especialização no decurso do $5^{\circ}$ Ano da licenciatura em Coimbra, Miguel Bombarda, sublinhará, em 1905, a importância do curso ministrado na nova instituição consagrada à regeneração sanitária do país ${ }^{(37)}$, retorquindo que os médicos que desejavam especializar-se em Medicina Legal se viam obrigados a frequentarem a cadeira de Direito Penal na Universidade, faltando provar "que um curso de direito penal seja necessário a um médico legista como o é a um

(34) António Ferreira Augusto, Assistência judiciaria, serviços medico-legaes, alienados criminosos, notariado, Porto, Imprensa Commercial, 1900, p. 33.

(35) Frédéric Chauvaud, Les Experts du crime. La Médecine légale en France au XIXe siècle, Paris, Aubier, 2000, pp. 104-105.

(36) Miguel Bombarda, "Instituto Central de Hygiene", A Medicina Contemporanea..., XVIII Anno, no 7, 18-II-1900, p. 54.

(37) Miguel Bombarda, "Medicos sanitarios... no papel", ibidem, XXIII Anno, n³, 15-I-1905, p. 17. 
higienista um tirocínio sanitário. [...] Enquanto o direito penal mais viver de fórmulas e de abstrusos metafisismos do que da realidade dos factos apurados pela moderna antropologia criminal quasi não servirá senão a barafundar os critérios médicos que pretendem ser lisos e positivos" (38).

\section{O segredo profissional}

Uma outra questão que evidencia o poder crescente do médico e as lutas com outros poderes é a que o sigilo médico suscitou. "Fundamento capital da relação entre médicos e clientes", a Medicina Contemporânea alertava para os modos como o médico podia, inadvertidamente, quebrar essa confiança. A necessidade de declarar a causa do óbito podia ser uma delas: confiante de que o documento não se destinava à publicidade, o médico parecia esquecer que, todavia, ele era um documento público, onde constariam todas os elementos de identificação; por exemplo, o clínico ao indicar como causa de morte, um aborto feito por uma rapariga solteira, podia, na verdade, revelar "segredos os mais comprometedores para a honra"(39). Mas não só. Quando o médico passava um atestado de doença comprometia, desnecessariamente, a regra fundamental da ética médica. Pois que necessidade teria o juiz em saber que uma testemunha não poderia comparecer por "estar preso ao leito por exostoses da tíbia?"; ou a escola em saber que o aluno que falta ao exame o faz por estar impedido pela "epidemite blenorrágica"?

Na verdade, só os médicos estariam em condições de compreender e julgar a causa da falta; e ao médico, titular de um diploma e por isso certificado o seu saber, "ninguém pode exigir-lhe a demonstração científica do asserto. O mesmo seria, para complemento do sistema exigir os fundamentos patológicos do diagnóstico feito" (40). A palavra do médico, voz da ciência, não admitia a necessidade da explicitação, nem perante a autoridade judicial. Posição que, evidentemente, não conseguiu colher aprovação: o perito em tribunal continuou a ser obrigado a explicitar e a p. 54 .

(38) Idem, " Instituto Central de Hygiene", ibidem, XVIII Anno, n 7, 18-II-1900,

(39) Ibidem, I Anno, n 17, 29-IV-1883, p. 133.

(40) Ibidem, IV Anno, nº 36, 5-IX-1886, p. 298. 
justificar o seu diagnóstico. A urgência em estabelecer medidas preventivas das epidemias não deixou, no entanto, de ajudar a matizar posições irredutíveis. A consciência crescente dos problemas sanitários do país levava a aceitar a obrigatoriedade de declarar doenças contagiosas, ainda que apenas suspeitadas. E mesmo que essa declaração dissesse respeito à maioria das doenças contagiosas - cólera, febre amarela, varíola, peste, escarlatina, difteria, febre tifóide e tuberculose -, outras havia que continuavam ao abrigo do segredo ${ }^{(41)}$. Assim, a sífilis e, nalguns casos, a febre puerperal continuavam a não exigir publicidade. A moral da sociedade - isto é, a moral construída pelas elites a que os médicos pertenciam - e a protecção das prerrogativas masculinas exigiam, nestes casos, outro tipo de profilaxia.

\section{A especialização profissional}

Nos inícios do século XX, a especialização disciplinar crescente tornou familiar e mesmo imprescindível, a presença do médico em múltiplas e novas situações, ainda que certos sectores continuassem a mostrar-se relutantes à preeminência médica. A ausência de médicos na direcção-geral de estatística é particularmente estranhada por Miguel Bombarda ${ }^{(42)}$. No entanto, a emergência da medicina escolar, do trabalho ${ }^{(43)}$, do desporto, a presença de médicos nas juntas de recrutamento - ainda que a título meramente consultivo ${ }^{(44)}-$, no ensino da anatomia ou de higiene dos edifícios nas escolas de Belas Artes ${ }^{(45)}$, a criação do curso de hematologista $^{(46)}$ no Instituto Bacteriológico, a presença de médicos nos estabeleci-

(41) A declaração de doenças contagiosas foi regulamentada por decreto de 3 de Dezembro de 1868, modificado por decreto de 28 de Agosto de 1893, que alarga o leque das doenças consideradas. Ibidem, XVIII Anno, nº 40, 7-X-1900, p. 334.

(42) Miguel Bombarda, "Serviços de Estatística", ibidem, XVI Anno, n² 29, 17-VII-1898, p. 232.

${ }^{(43)}$ Oliveira Feijão, "Actualidades. Previdencia e acidentes de trabalho", ibidem, XXV Anno, n 47, 24-XI-1907, p. 375.

${ }^{(44)}$ Miguel Bombarda, "Leis contra a sciencia", ibidem, XXI Anno, $\mathrm{n}^{\circ}$ 52, 27-XII-1903, p. 413.

(45) "Variedades. Anatomia artística e hygiene dos edificos", ibidem, XXVIII Anno, n² 24, 12-VI-1910, p. 192. 
mentos termais, que começam a conhecer grande desenvolvimento (e que acasalavam o lazer com os cuidados de saúde), sem esquecer a habilitação profissional específica, obtida com um curso de Medicina Colonial ${ }^{(47)}$ para os médicos destinados ao Ultramar, são manifestações que dão conta do poder crescente deste grupo profissional e que permitem compreender as suas estratégias tanto para assegurar o monopólio de um mercado, como através da segmentação e especialização profissional impedir a saturação. Um médico escolar não visava a mesma clientela de um obstetra e um alienista não competia, directamente, com um oftalmologista. Por isso, a entrada de novos profissionais continuava a ser bem-vinda. Isso mesmo se pode inferir da notícia publicada, em 1914, nas páginas da Vida Médica e Scientífica: a densidade médica no Portugal Continental era, nesta data, de 3,3 médicos por 10000 habitantes, número muito inferior ao dos outros países europeus. Acrescia ainda a desigualdade da distribuição territorial dos facultativos: só nos concelhos de Espinho, Porto, Gaia, Coimbra e Lisboa, as taxas se aproximavam às europeias ${ }^{(48)}$.

\section{A sociabilidade profissional}

Uma mobilização profissional mais regular e consistente dos diplomados em medicina, capaz de regulamentar o exercício da profissão, foi um dos desideratos mais difíceis de realizar. Uma primeira iniciativa, em 1883, centrada na assistência mútua - na doença e morte -, ficou $\operatorname{gorada}^{(49)}$. Note-se que os socorros mútuos foram um dos caminhos que, em Portugal, ajudaram a consolidar a emergente consciência profissional, fosse ela operária ou liberal ${ }^{(50)}$. Só na década de 90 , os médicos conse-

(46) "Variedades. Curso de Hematologia", ibidem, XXIII Anno, n²0, 7-V-1905, p. 152.

${ }^{(47)}$ Miguel Bombarda, "Sociedade de Sciencias Medicas de Lisboa. A creação de uma Escola de medicina colonial", ibidem, XIX Anno, nº 43, 27-X-1901, p. 350.

(48) "Densidade da população médica em Portugal", Vida Médica e Scientífica, I Ano, nº 2, Fevereiro 1914, pp. 92-94.

(49) Ibidem, III Anno, n 19, 10-V-1885, p. 145.

(50) Sobre a dimensão do movimento mutualista veja-se Costa Goodolfim, A Previdencia. Associações de socorro mutuo, cooperativas, caixas de pensões e reformas, caixas economicas, Lisboa, Imprensa Nacional, 1889. 
guiram formar e manter a Associação dos Médicos Portugueses, no seio da qual os problemas da profissão, externos ou internos, podiam ser debatidos. Esta Associação, nos inícios da República, encontrava-se já dividida em três agremiações, sediadas, respectivamente, no Porto ${ }^{(51)}$, em Coimbra ${ }^{(52)}$ e em Lisboa, reunindo os médicos mais importantes dos três centros. E a força do grupo era já tal que conseguiam, em 1912, realizar o seu primeiro Congresso Nacional de Deontologia e Interesses Profissionais.

Os médicos que exerciam nos meios rurais também perceberam ser do seu interesse a formação de uma agremiação que considerasse a sua situação particular e, em 1914, constituem uma União dos Médicos Provinciais elegendo, do mesmo passo, uma comissão permanente em Lisboa, que tratasse "junto dos poderes públicos dos seus interesses profissionais"(53). Não surpreende, por isso, a escolha dos nomes dos clínicos lisboetas que integraram este órgão: Oliveira Feijão, Belo Morais, Egas Moniz, Augusto Monjardino, Nicolau Bettencourt, Francisco Gentil, Borges de Sousa e Azevedo Neves, eram personalidades bem conhecidas, quer dos meios académico-científicos, quer dos meios políticos. Com esta comissão, os médicos de província julgavam assegurar uma maior proximidade ao(s) poder(es), mas a elite médica de Lisboa também assegurava o controlo e o enquadramento dos seus colegas provinciais.

A Associação dos Médicos Portugueses foi vigilante e incansável na defesa dos interesses corporativos. A título de exemplo, recorde-se a sua posição, pela voz de Augusto Vasconcelos, lente da Escola Médico-Cirúrgica de Lisboa, perante a criação de uma policlínica que, com preços reduzidos, procurava tornar mais acessíveis os cuidados de saúde aos grupos economicamente mais desfavorecidos. Sintomaticamente, prognosticava "que a concorrência assim estabelecida pela instituição das policlínicas $[\ldots]$ virá a tornar-se perigosa [...], que o princípio da concorrência por abaixamento de preços [...] será perigoso e prejudi-

(51) Em 1914, a Associação dos Médicos do Norte de Portugal modificava os seus estatutos e tomava o nome de Associação Médica Lusitana. A Medicina Contemporanea..., Anno XXXII, nº 6, 8-II-1914, p. 48.

${ }^{(52)}$ Em Dezembro de 1911, por iniciativa do médico Carlos Dias, constitui-se a Associação dos Médicos de Coimbra.

(53) "Actualidades. União dos médicos provinciaes", ibidem, XXXII, n 44, 1-XI-1914, p. 354. 
cialíssimo processo que indubitavelmente trará à classe um desprestígio e diminuição de autoridade", concluindo que "a organização de consultórios com preços reduzidos para as classes menos abastadas não constitui socialmente uma impreterível necessidade"(54).

Mais importante para a saúde das classes laboriosas parecia ser a melhoria das condições hospitalares. A especialização hospitalar e a higienização dos hospitais foram dos assuntos mais debatidos e reivindicados, o que não surpreende, já que foram raros os hospitais criados de raiz ${ }^{(55)}$, durante a Monarquia Constitucional. $\mathrm{O}$ aproveitamento de velhos conventos secularizados não proporcionava as condições de higiene, de ar, luz e limpeza que um hospital deveria ter. A má alimentação, a sobrelotação dos espaços, a falta de pessoal treinado e de equipamento são motivos de queixas e reivindicações constantes. As dificuldades em estabelecer sanatórios, marítimos ou de altitude, para o tratamento dos diferentes tipos de tuberculose, são outros indicadores da indigência das infraestruturas médicas do país ${ }^{(56)}$. As enfermarias do Hospital do Desterro e, nos inícios da década de 1880, a situação do Hospital de Rilhafoles serão regularmente apontados como exemplos do muito que haveria a fazer para proporcionar cuidados médicos condignos.

E, se a acção de Miguel Bombarda na reorganização do Hospital de Rilhafoles foi exemplar, ainda havia muito por fazer nos inícios da República. A necessidade de uma maternidade - que deveria chamar-se Alfredo da Costa -, por exemplo, é insistentemente apontada em 1912, e recordadas as promessas da sua edificação ${ }^{(57)}$.

Para se perceber melhor a construção do poder médico no século XIX ter-se-á ainda de levar em conta a Sociedade das Ciências Médicas de Lisboa, devido ao seu papel na emergência do médico como homem de ciência, na discussão das novas ideias e como local onde se reuniam regularmente os médicos de Lisboa para apresentarem e discutirem os

(54) "Associação dos medicos portugueses", ibidem, XXIII Anno, n² 25, 18-VI-1905, pp. 198-9.

(55) O hospital D. Estefânia e o hospital do Rego, para doenças contagiosas, são excepções.

(56) José Tomás Sousa Martins, $A$ tuberculose e o clima de altitude da Serra da Estrela, Lisboa, Imprensa Nacional, 1890.

(57) "Sociedade de Sciencias Medicas", AMedicina Contemporanea..., XXX Anno, $\mathrm{n}^{\circ} 16,21-\mathrm{IV}-1912$, p. 125. 
casos mais difíceis. E se o seu objectivo primeiro apontava para o desenvolvimento científico, o certo é que ela também funcionou como reforço da consciência profissional, ao actuar, bastas vezes, como associação profissional, zelando pelos interesses da classe médica.

Fundada em 1835, cedo os poderes a reconheceram como centro científico que poderia aconselhar a "orientação das coisas médicas do país"(58). Frequentemente, o Estado recorreu à Sociedade de Ciências Médicas, em assuntos tão variados quanto o foram as consultas sobre a colonização (1850), o trabalho dos menores (1880), as epidemias de cólera (1886), o melhoramento do porto de Lisboa sob o ponto de vista sanitário (1884) ou o regimen alcoólico (1888). Também as autarquias e, em particular, a Câmara de Lisboa mantiveram laços próximos com a Sociedade, consultando-a sobre o abastecimento de carne (1860), a salubridade da capital (1859) ou os cemitérios e a cremação (1881). E mesmo que o Estado nem sempre tivesse sentido a necessidade de escutar a opinião médica, a Sociedade inúmeras vezes alertou o poder público para questões que exigiam soluções prementes, ou pedindo a correcção de propostas legislativas. Assim, recomendou ao Estado uma solução urgente para a deficientíssima hospitalização dos alienados (1841), aconselhou a adopção do sistema métrico (1842), pediu que lhe fosse cedido o corpo ou pelo menos a cabeça de Matos Lobo para estudo (1842) e reivindicou, insistentemente, a reforma dos serviços médico-legais, exigência à qual se juntaram as direcções da Sociedade dos Advogados e Farmacêutica Lusitana (1879).

O trabalho da Sociedade não se esgotou, porém, na produção de pareceres ou reivindicações. Trabalhou arduamente na discussão e no estudo da profilaxia e tratamento de epidemias, promoveu sessões de propaganda da vacinação jenneriana, e organizou sessões de vacinação gratuita nas suas salas. A raiva e a tuberculose foram motivos de discussões e conferências, sem esquecer que foi dos relatórios apresentados na Sociedade, em 1899, "que saiu a Liga contra a tuberculose"(59).

Como se verifica por esta síntese do que foi o trabalho desta associação científica, a medicina não recusava a sua vocação social. As redes de sociabilidade que se foram construindo, dentro e fora da Sociedade de

(58) "A Sociedade das Sciencias Medicas de Lisboa no seculo XIX", ibidem, XIX Anno, no 43, 27-X-1901, pp. 355-358.

(59) Ibidem, p. 357. 
Ciências Médicas de Lisboa, permitiram que a voz dos médicos fosse cada vez mais audível. Para o que contribuiu, largamente, o aparecimento de uma imprensa médica especializada - Lisboa, nos inícios da década de 1880 contava com quatro revistas médicas ${ }^{(60)}$-, a colaboração de médicos em jornais diários, a realização de conferências de propaganda higienista ${ }^{(61)}$, bem como a formação de associações profilácticas - de que se destaca a Liga Nacional contra a Tuberculose, cuja sessão inaugural se realizou em 1900 - e o reconhecimento internacional que a participação em Congressos permitia, não esquecendo também a pertença a outros círculos e grupos com acesso privilegiado aos centros de decisão. O médico, pela sua origem social, pelo diploma e pela sua participação nestas redes de influência ia conquistando um poder crescente.

Talvez seja a sua presença no Parlamento o melhor indicador acerca do crescimento e do reconhecimento social do poder médico. Recorde-se o peso das profissões liberais na Câmara dos Deputados e o número de médicos que aí tomaram assento. Segundo Pedro Tavares de Almeida ${ }^{(62)}$, em 1861, 7 médicos foram eleitos deputados, 5 em 1872, 8 em 1880 e 17 em 1890. Porém, em 1908, 14 deputados eram médicos, entre os quais se contavam António José de Almeida, Miguel Bombarda, Egas Monize Brito Camacho(63). Mas será com a República que os médicos alcançam, na verdade, todo o seu poder: a Assembleia Constituinte, em 1911, contou

${ }^{(60)}$ Gazeta Medica de Lisboa, Revista Medica Portugueza, Jornal da Sociedade de Sciencias Medicas de Lisboa e A Medicina Contemporanea. Em 1894, surgiria ainda a Revista de Medicina e Cirurgia.

${ }^{\left({ }^{61}\right)}$ Em 1904, realizaram-se em Lisboa uma série de conferências de propaganda cujos temas abarcaram: a falsificação dos géneros alimentícios, a carestia da vida, a higiene profissional, a proteç̧ão dos indigentes e da infância, a malária, a sífilis, o alcoolismo, a degenerescência, a profilaxia das doenças epidémicas, a habitação do pobre, o abastecimento de água, a limpeza das ruas e o sistema de esgotos. Para o programa completo com o nome dos conferencistas, cf. AMedicina Contemporanea..., XXII Anno, $\mathrm{n}^{\circ}$ 1, 3-1-1904, p. 8.

(62) Pedro Tavares de Almeida, Eleições e caciquismo no Portugal oitocentista (1868-1890), Lisboa, Difel, 1991, p. 185.

${ }^{(63)}$ A título de exemplo, no ano de 1908, o Parlamento contava com os seguintes deputados médicos: Queirós Veloso, Mateus Sampaio, Egas Moniz, Miguel Bombarda, Sabino Coelho, Archer da Silva, José Jardim, Silva Amado, Eduardo Burnay, António José de Almeida, Estêvão de Vasconcelos, Libânio Fialho, Brito Camacho e Ramada Curto. 
50 médicos e dois estudantes de medicina entre os seus deputados ${ }^{(64)}$, constituindo o grupo profissional mais representado ${ }^{(65)}$, permitindo-lhes levar à atenção da Câmara os assuntos e diplomas que directa ou indirectamente diziam respeito à sua profissão.

Se, em 1898, a realização de um Congresso de Medicina, não conseguiu a audiência internacional desejada, o Congresso de 1906, realizado em Lisboa foi o coroamento do prestígio da medicina portuguesa. Largamente participado por médicos portugueses e estrangeiros (o congresso reuniu cerca de seis mil participantes), os seus organizadores - e entre eles destacava-se Miguel Bombarda - conseguiram que o novo edifício da Escola Médico-Cirúrgica fosse terminado a tempo de aí receber, com pompa e circunstância, os congressistas. Se é verdade que nenhuma novidade científica revolucionária foi apresentada, o forum permitiu a troca de ideias, e incentivou ou fortaleceu laços de solidariedade, nacionais e internacionais. As visitas a alguns hospitais e serviços, que eram prática habitual destas reuniões, incentivaram a sua melhoria, de modo a apresentar-se o sistema de saúde do país de acolhimento a uma melhor luz e a projectar uma boa imagem dos médicos portugueses dentro da comunidade científica internacional, assim como do seu peso e influência no campo prático, e particularmente no que respeitava às questões higienistas ${ }^{(66)}$.

Como consequência de toda esta ofensiva, a opinião pública e os poderes também iam ficando mais convencidos do "fundo alicerce médico em que assentam as questões sociais" ${ }^{\prime(67)}$, fossem elas o regimen

(64) Para a listagem dos médicos nesta Assembleia, cf. "Medicos nas Constituintes", A Medicina Contemporanea..., XXIX Anno, n² 24, 11-VI-1911, p. 131.

${ }^{(65)}$ Os médicos e farmacêuticos, eleitos na $1^{\text {a }}$ legislatura republicana, representam 18,1\% dos eleitos; seguiam-se-lhes os advogados $\left(16,3^{\circ}\right)$ e os militares (13,7\%), Pedro Tavares de Almeida, Marta Carvalho dos Santos e Paulo Jorge Fernandes, "Deputados e Senadores. O Recrutamento parlamentar na I República", in $2^{\circ}$ Colóquio sobre História das Elites, Lisboa, ICS, Nov. 2003 (no prelo). Agradeço esta indicação ao Paulo Jorge Fernandes

(66) Anne Rasmussen, "L'Hygiène en congrès (1852-1912): circulation et configurations internationales", in Les Hygiénistes. Enjeux, modèles et pratiques..., pp. 227-228.

(67) Miguel Bombarda, "Patriotismos", A Medicina Contemporanea..., XXIII Anno, n' 2, 8-I-1905, p. 11. 
penitenciário(68), o conteúdo do ensino secundário(69), os seus horários e o tipo de escrita mais aconselhável ${ }^{(70)}$, o descanso dominical ${ }^{(71)}$, o industrialismo, os acidentes de trabalho ${ }^{(72)}$, o trabalho infantil ${ }^{(73)}$, ou o feminismo, e pareciam acreditar, cada vez mais, que a ordem da sociedade poderia ser conseguida sob a iluminação da luz tutelar da ciência médica. Não surpreende, pois, o prestígio social do médico, elite entre as elites intelectuais e que ousava chamar a si não só a cura dos corpos individuais, mas também a tarefa imensa de regenerar Portugal.

\section{Uma visão totalizadora}

Em 1884, na série de conferências já referidas, suscitadas pelos receios de uma epidemia de cólera, Ricardo Jorge traçava o programa da medicina e da higiene a partir de uma pretensão epistemológica totalizadora. É que elas deviam apropriar-se "dos dados preciosos das ciências auxiliares, da física e da química que lhes dão a chave da fenomenalidade geral da força e da matéria, e da biologia que lhes rasga a funcionalidade e a morfologia viva, em toda a série das suas individualizações progressivas"; teriam ainda de "desdobrar as páginas da história do globo, estampadas nas camadas geológicas"; de folhear "a história inteira da humanidade, desde o humilde documento paleoarqueológico aos monumentos da civilização completa; a psicologia perscruta-lhes as rodas complexas da máquina mental e a antropologia a génese do homem, a formação e a dispersão das raças; a sociologia enfim indaga-lhes das variadíssimas funções das sociedades e do viver complexo de toda a

${ }^{(68)}$ Idem, "Regimen penitenciario", ibidem, XXVI Anno, n² 28, 12-VII-1908, p. 217.

(69) "Actualidades. A questão do ensino secundario", ibidem, XX Anno, $\mathrm{n}^{\circ} 51$, 21-XII-1902, p. 407.

(70) "Bibliographia. Atitudes viciosas nas escolas, por Costa Sacadura", ibidem, XXV Anno, n 3, 20-I-1907, p. 20.

(71) Ricardo Jorge, "O descanso dominical", ibidem, XX Anno, nº 8, 23-II-1902, p. 61.

(72) Oliveira Feijão, "Actualidades. Previdência e Acidentes de trabalho", ibidem, XXV Anno, $\mathrm{n}^{\circ}$ 47, 24-XI-1907, pp. 373-376.

(73) Ibidem, IV Anno, n 8, 21-II-1886, p. 65. 
humanidade. Esta é a penosa escala que tem a percorrer o médico e o higienista que podem dizer [...] Medicus sum, nihil a me alienum puto"(74). Vasto programa taxinómico que colocava o médico no topo de uma pirâmide de saber, articulando as diversas contribuições "de todos os raios científicos, de todo o saber e de toda a verdade"(75). Mas como a realidade estava distanciada do que as ciências propunham, o papel do médico era o de um apóstolo, que deveria, em primeiro lugar, chamar às suas responsabilidades o poder público. Entende-se. Em função do iluminismo esclarecido que animava o proselitismo médico, a saúde dos povos era um dever do Estado decorrente da aceitação da Declaração Universal dos Direitos do Homem que, implicitamente, a Carta Constitucional aceitava. E Ricardo Jorge estava certo de que breve chegaria o dia em que os reorganizadores do Estado compreenderiam que a regeneração higiénica do país só se poderia fazer através de uma articulada e descentralizada reforma sanitária, condição básica de todas as reformas sociais.

Tendo em conta que nada devia ser estranho à medicina e ao médico, e dado o lugar e a atenção que as condições mesológicas - "alma de todo o progresso"(76) - deviam suscitar, não surpreende a atenção dada aos factores climáticos e meteorológicos. As condições climatéricas suscitarão múltiplas ilações, desde as que estabeleciam uma relação directa entre um clima frio e uma maior propensão para as práticas democráticas ${ }^{(77)}$, até às que, em Portugal, e a partir do Ultimatum, começaram a sustentar a maior vocação colonizadora dos povos do Sul da Europa, em particular a dos habitantes da Península Ibérica, mais adaptados ao calor ${ }^{(78)}$. A meteorologia também é olhada com atenção, pois dela dependia a eclosão e mais fácil transmissão de doenças e com ela se relacionava a maior ou menor mortalidade. Assim, explica-se que nas revistas médicas fossem publicadas as estatísticas demográficas e nosográficas, a par dos quadros das condições meteorológicas que

(74) Ricardo d'Almeida Jorge, A Hygiene Social..., p. 42.

(75) Idem, ibidem.

(76) Idem, ibidem, p. 5.

(77) Miguel Bombarda, "A raça negra", A Medicina Contemporanea..., XXIII Anno, no 35, 27-VIII-1905, p. 274.

(78) Ibidem, VIII Anno, suplemento ao n 37, 17-IX-1890, p. 297. 
também ajudavam a explicá-las. Com efeito, importa não esquecer que o saber demográfico se foi impondo como um factor essencial da governabilidade típica do Estado moderno.

\section{Patologias urbanas e medos sociais}

Dadas as condições em que viviam as gentes do meio rural, não pode deixar de se estranhar a pouca atenção que os médicos, isto é, aqueles que conseguiam que a sua voz fosse ouvida, lhes prestaram, apesar da imprensa diária e da especialidade não deixar de noticiar o aparecimento de epidemias que, constantemente, afligiam as províncias. Alguns médicos reconheciam na miséria rural a causa da morbidez, e surpreendiam-se por os campos, afinal, não oferecerem um quadro de saúde mais de acordo com as ideias preconcebidas que idealizavam os ares campestres $^{(79)}$. Entre os trabalhos académicos produzidos na primeira década do século XX que se consultaram, só um se propôs tratar do estado da higiene rural do país ${ }^{(80)}$ e mesmo este, sublinhou, inequivocamente, a superioridade das condições higiénicas do meio rural quando comparadas com os perigos sanitários a que a cidade estava sujeita. Verdade é que a Medicina Social se impôs, em primeiro lugar, como uma medicina urbana ${ }^{(81)}$. Já durante o período republicano, a atenção prestada às deficientes condições higiénicas do meio rural foi mais crítica: lembrando que a tuberculose e o tifo exantemático eram epidemias que afectavam, sobremaneira, os campos portugueses ${ }^{(82)}$, sublinhava-se, ainda, que as

${ }^{(79)}$ Sociedade de Geographia de Lisboa, Expedição Scientifica à Serra da Estrella em 1881. Secç̧ão de Medicina, sub-seç̧ão de ophtalmologia. Relatorio do sr. Dr. Francisco Lourenço da Fonseca Júnior, Lisboa, Imprensa Nacional, 1883, pp. 11-13.

(80) António Eduardo Silva, Algumas palavras sobre o estado da Hygiene rural no nosso paiz. Dissertação inaugural apresentada à Escola Medico-Cirurgica de Lisboa, Lisboa, Typographia de Francisco Luís Gonçalves, 1910.

${ }^{(81)}$ Michel Foucault, "O Nascimento da Medicina Social", in Microfísica do Poder, Rio de Janeiro, Graal, 2002, pp. 89-93.

${ }^{(82)}$ A propósito da terrível mortalidade provocada pelo tifo exantemático veja-se, Maria Lúcia Brito Moura, A Epidemia de tifo em Loriga (1927), separata da Revista de Gestão e Desenvolvimento, vol. 5-6, 1996-1997. 
doenças mentais também eram problema rural ${ }^{(83)}$ e procurava-se matizar a visão idílica dos camponeses, construída e divulgada com a ajuda da literatura dos finais de Oitocentos e inícios do século $X X^{(84)}$.

Seja como for, nesta conjuntura, a atenção dos médicos, está sobretudo virada para o meio urbano. Diga-se, desde já, que, apesar dos desenvolvimentos da ciência e das transformações económicas decorrentes da revolução industrial, as elites parecem manter uma antiga visão demoníaca da cidade.

Pela acumulação de fábricas e manufacturas, pelo crescimento populacional, pelas más condições de habitação, pela ausência de infraestruturas, a cidade parece mais ameaçadora do que nunca. Não é que os muitos e complexos problemas urbanos não exigissem, e urgentemente, soluções e reformas. Mas é que, a par das dificuldades que se diagnosticam, parece manter-se uma visão da cidade que não aceita facilmente a vida urbana em toda a sua variedade e riqueza. Compreende-se. A ordem que se desejava para a cidade visava a uniformização e a realidade parecia afastar-se, cada vez mais, deste modelo sonhado.

Assim, a migração crescente das gentes do campo para a cidade é vista, contraditoriamente, ora como a destruição do bom selvagem (que era arrancado da natureza para ser aniquilado, moral e fisicamente, na civilização urbana), ora como um dos meios de o civilizar, se as condições de vida pudessem estar mais conformes com os ditames do higienismo. Deste modo, na cidade - e como já era assinalado em 1892 -, "a inferioridade física, a degeneração orgânica e enfraquecimento funcional que a sociabilidade determina quando transforma a população rural em urbana, quando aumenta a densidade desta, quando torna mais acesa a luta pela vida nos grandes centros, este resultado negativo precisa ser combatido com energia e pertinácia" ${ }^{\prime(85)}$. Note-se como a retórica de um certo darwinismo social ia sendo invocada para legitimar as medidas a tomar. Dir-se-ia que as condições miseráveis (condições artificiais decorrentes de uma má configuração política e social que o meio urbano

${ }^{(83)}$ Guilherme Ennes, "Nevroses", A Medicina Contemporanea..., XXX Anno, $\mathrm{n}^{\circ}$ 9, 3-III-1912, p. 66.

(84) Manuel de Vasconcellos, "Chronica Medica. Vida do campo", ibidem, XXXI Anno, n 27, 6-VII-1913, p. 215.

(85) Silva Carvalho, "Revista de Hygiene", A Medicina Contemporanea..., X Anno, 12-VI-1892, p. 189. 
ajudava a revelar), em que grande parte da população sobrevivia na cidade, aceleravam o struggle for life, transtornando os mecanismos naturais da sobrevivência dos mais aptos. A tarefa do higienista, ao apontar os caminhos da reforma sanitária, era, num certo sentido, repor um equilibrio natural adulterado pela civilização urbana, que artificial e injustamente ia eliminando, porventura, os mais fortes e aptos, provocando, com isso, o progressivo enfraquecimento da raça ${ }^{(86)}$.

Como primeira medida, defendia-se a colocação dos serviços de sanidade na dependência da autarquia. Desiderato que teve uma primeira e passageira realização em 1885, com o projecto de reforma do município de Lisboa, da autoria do ministro Barjona de Freitas. Redefinindo os pelouros camarários, o serviço de Saúde e Higiene Públicas asseguraria, com plena autonomia, os serviços sanitários. A cidade era dividida em vinte e uma circunscrições, tuteladas por um sub-delegado de saúde, de nomeação municipal, com "extensíssimas atribuições de polícia sanitária, de assistência clínica, [...] [de] registro demográfico; [de] registro nosográfico [...] de estudo das causas de insalubridade; [...] além disso, os sub-delegados têm que dedicar duas horas por dia para consultas médicas a pobres [e] são obrigados a vacinar gratuitamente nas suas circunscrições" (87). A vigilância sobre escolas, oficinas, creches, hospitais, feiras, cafés, casas de malta, matadouros, igrejas e cemitérios, canalizações, qualidade das águas, chafarizes e poços fazia parte do dia a dia dos sub-delegados, que deviam ainda reunir-se em conselhos de bairro para, em conjunto, propor medidas de intervenção. Note-se como a intenção de esquadrinhamento sanitário-policial do tecido urbano tomava forma. Os diversos registos e procedimentos de identificação visavam fornecer uma visão panóptica da cidade aos poderes.

A reforma de Barjona de Freitas foi saudada como um passo dado no bom caminho, mas a extensão das atribuições destes funcionários e os fracos recursos financeiros disponíveis para a solução dos problemas suscitaram, novamente, uma centralização dos serviços no Governo Civil. No entanto, o impacto do trabalho de Ricardo Jorge, por ocasião do surto

${ }^{(86)}$ Irene Maria Vaquinhas, “O conceito de 'decadência fisiológica da raça' e o desenvolvimento do desporto em Portugal (finais do século XIX/princípios do século XX)", Revista de História das Ideias, vol. 14, 1992, pp. 365-388.

${ }^{(87)}$ A proposta detalhada encontra-se em A Medicina Contemporanea ..., III Anno, no 16, 19-IV-1885, pp. 121-122. 
de peste bubónica em 1899, no Porto, acabou por convencer os poderes da necessidade de uma reforma profunda. E aos que, em 1902, estranhavam o poder higienista, alcançado à custa das liberdades e direitos individuais, Miguel Bombarda lembrava que, nestas matérias, só os médicos eram autoridades competentes e que, acima dos direitos individuais, alguma coisa superior havia ${ }^{(88)}$. Tal como Ricardo Jorge já sublinhara a noção de pecado físico tardava em permear as consciências ${ }^{(89)}$.

A reflexão sobre os diversos problemas do estado sanitário da capital foi uma preocupação constante. Desde a qualidade da água ${ }^{(90)}$, à falta de esgotos $^{(91)}$ e canalizações, passando pelo deficiente tratamento dos resíduos, pelos processos de limpeza urbana, pelo abastecimento de alimentos em bom estado ${ }^{(92)}$, pela distribuição do pão ${ }^{(93)}$ e venda ambulante de leite, pelos preços dos géneros, pelas condições de salubridade das casas $^{(94)}$, aos cemitérios e modo de enterramento, tudo na cidade é motivo de escândalo higienista. Mas, com o pelouro de higiene e saúde pública atribuído a Sabino Coelho, professor da Escola Médico-Cirúrgica, o diagnóstico dos males, pelo menos, não falhava.

A par dos problemas gerais da cidade, os médicos propunham, igualmente, providências urgentes sobre alguns pontos mais sensíveis. O "rasgamento de Alfama" é, talvez, uma das propostas mais radicais. Miguel Bombarda não acreditava na possibilidade de recuperação deste bairro da cidade, que descrevia assim: "vielas tortuosas e lôbregas, moradias soturnas e infectas, aquela acumulação habitacional com becos de $50 \mathrm{~cm}$ de largo e prédios em que se vive em casa dos vizinhos, aquele enxame de gente, aquele amontoado de casas [...] Coisas imundas, coisas

${ }^{(88)}$ Miguel Bombarda, "Progressos", ibidem, XX Anno, n 1, 5-I-1902, p. 9.

(89) Ricardo Jorge, A Hygiene Social..., p. 6.

(90) "Variedades. Abastecimento de aguas em Lisboa", A Medicina Contemporanea..., XXVI Anno, $\mathrm{n}^{\circ}$ 14, 5-IV-1908, p. 112.

${ }^{(91)}$ Miguel Bombarda, "Exgottos de Lisboa", ibidem, XX Anno, n 9, 2-III-1902, p. 68 .

(92) "Variedades. Alimentação e hygiene em Lisboa", ibidem, XXVI Anno, $\mathrm{n}^{\circ} 12,22-$ III-1908, p. 96.

(93) "Variedades. Venda de pão em Lisboa", ibidem, XXVII Anno, n 49, 5-XII-1909 , p. 402.

(94) As más condições das habitações encontram-se bem descritas em Inquerito aos pateos de Lisboa. Anno de 1902, Lisboa, Imprensa Nacional, 1903. 
asquerosas, coisas desafiando os mais negros voos da imaginação [...] Não são só os pátios onde formiga uma população esfarrapada e desconhecendo as noções mais rudimentares do asseio do corpo ou da casa [...] São ainda as cités operárias que se fizeram com o ignóbil aproveitamento dos velhos palácios desabitados [...] tudo foi aproveitado para cubículos infectos [...] E vivem ali centenas de criaturas humanas na mútua infecção, no mais atroz imundismo, e quantas vezes no vício, na descompostura e na desordem"(95).

Note-se como, na descrição do director da Medicina Contemporânea a associação entre classes laboriosas, perigosas e viciosas se fortalecia ${ }^{(96)}$. Nestes meios de barracas e vilas, situados perto das fábricas e outras indústrias, as mais insalubres, amontoavam-se os recém-chegados à cidade. Aí campeavam livremente as doenças e epidemias e grassavam comportamentos que as elites procuravam disciplinar: exigiam-se maior contenção de gestos, hábitos de trabalho regulares, relações familiares e pessoais mais pacíficas, linguagem mais morigerada, em suma, modos de vida mais padronizados e sociabilidades mais conformes ao modelo definido pelas elites como normal e apropriado. Acreditava-se que as condições mesológicas, físicas e sociais, tinham um papel determinante nos comportamentos. E estes, por seu lado, também ajudavam a explicar o quadro nosográfico. Assim, o pensamento higienista visava não só melhorar as condições concretas da existência, mas também a educação destes grupos sociais. Só uma inculcação persistente da moral e dos valores, tidos como adequados (porque inspirados em ditames científicos), poderia conduzir à interiorização das normas higiénicas.

Ora, há que entender que, no Portugal dos finais de Oitocentos e inícios do século $X X$, as endemias como o paludismo, ou as epidemias de varíola, tifo, cólera, tuberculose e sífilis depauperavam, sistematicamente, uma população pobre, analfabeta e mal alimentada. E as resistências às medidas sanitárias e/ou terapêuticas estavam longe de ser apanágio exclusivo destes grupos mais desfavorecidos. Recordem-se as objecções à obrigatoriedade da vacina anti-variólica: desde aqueles que

(95) Miguel Bombarda, "O bairro de Alfama", A Medicina Contemporanea..., XXI Anno, nº 9, 1-III-1903, p. 68.

(96) Esta associação era já clássica nos finais do século XIX. Veja-se, a título de exemplo, H. A. Frégier, Des classes dangereuses de la population dans les grandes villes et des moyens de les rendre meilleures, Bruxelles, Meline, Cans et Cie., 1840, p. 21. 
invocavam a defesa da liberdade individual, até aos que, em nome da ciência, ainda levantavam dúvidas quanto à eficácia da vacinação ${ }^{(97)}$. É verdade que, em Portugal, o método mais usado era o da inoculação braço a braço - mais barato, evidentemente -, com os riscos evidentes de contaminação de outras doenças. Os receios e desconfianças expressos (em outros países suscitaram mesmo congressos anti-vacínicos), se não conduziram, no nosso país, a um movimento organizado, dificultavam, no entanto, o controlo da varíola. Entre 1879 e 1888, por exemplo, o Instituto Campos \& Bourquin, responsável por grande parte da vacinação efectuada em Lisboa, apenas vacinou 9545 pessoas $^{(98)}$. E, ainda em 1906, não só em Fornos de Algodres os pais se recusavam a permitir a vacinação dos seus filhos ${ }^{(99)}$; perto de Lisboa isso também aconteceu: em Caneças, a população organizou, como alternativa, uma procissão de penitência como remédio para a epidemia ${ }^{(100)}$.

E não eram só os habitantes que tinham dúvidas quanto à eficácia das medidas propostas pelos médicos. Também a imprensa e os poderes tardaram, muitas vezes, a aceitar a voz da ciência. Recorde-se que, nos anos de 1884, 1885 e 1886, apesar da insistência dos médicos em garantir que, no controlo da epidemia do cólera, o cordão sanitário não surtiria efeito, o governo ordenou-o e manteve-o, com custos financeiros elevados ${ }^{(101)}$. Só em 1899 , aquando da epidemia de peste bubónica no Porto, o Estado pareceu confiar no poder da medicina com bons resultados: a epidemia foi contida sem quarentena da cidade.

E se em alguns casos as medidas profilácticas pareciam dar razão aos médicos - a mortalidade pela febre tifóide baixou através de um maior controlo da qualidade da água ${ }^{(102)}$-, outras epidemias, no entanto, não cediam. A tuberculose e a sífilis pareciam exigir, como medidas profi-

${ }^{(97)}$ Mathew Ramsey, "Mouvements anti-hygiènistes et libéralisme: vers une histoire comparée", Les Hygiénistes..., pp. 319-340.

(98) "Variedades. Vaccinação e revaccinação obrigatórias", A Medicina Contemporanea, XIV Anno, n 18, 3-V-1896, p. 143.

${ }^{(99)}$ O Seculo, XXVI Anno, $\mathrm{n}^{\circ} 8754,11-\mathrm{V}-1906, \mathrm{p} .3$.

(100) Ibidem, XXVI Anno, $\mathrm{n}^{\circ}$ 8769, 26-V-1906, p. 5.

${ }^{(101)}$ A Medicina Contemporanea..., IV Anno, nº 12, 21-III-1886, p. 97.

${ }^{(102)}$ Com a proibição de utilização de poços e cisternas e a introdução de água do Alviela a mortalidade pela febre tifóide parece ter decrescido substancialmente. "Actualidades. Febre typhoide em Lisboa", A Medicina Contemporanea..., XXVII Anno, n³ 35, 29-VII-1909, p. 285. 
lácticas, uma profunda alteração de hábitos, comportamentos e valores, individuais e sociais.

Nesse sentido, iam as conclusões dos congressos contra a tuberculose que, não deixando de chamar o Estado às suas responsabilidades pela deficiente organização político-social e pelo escasso investimento na investigação bacteriológica, apontavam a aglomeração provocada pelo trabalho industrial, a concentração populacional das cidades, as habitações insalubres e a moral - ou melhor a falta dela - como razões que ajudavam a explicar o rápido contágio da doença nos grupos sociais mais desfavorecidos ${ }^{(103)}$.

Os outros pareciam estar mais protegidos, devido a uma superioridade física manifesta, que estava comprovada pela antropologia, e apenas se encontravam ameaçados pela convivência, mais ou menos próxima mas inevitável, com as "classes pobres". Daí deverem interessar-se pela promoção da profilaxia social ${ }^{(104)}$.

Compreende-se, neste contexto, a insistência em medidas que visavam limitar os contactos entre os corpos, como a exigência do uso de luvas aos funcionários da Alfândega que procedessem à revisão das bagagens, a repugnância demonstrada pelo hábito dos revisores dos carros eléctricos lamberem os dedos antes de cortar os bilhetes ${ }^{(105)}$. E estes medos eram tão fortes que, em 1905, se fundou uma Liga contra os apertos de mão ${ }^{(106)}$. A disciplina higiénica do corpo ia conseguindo inculcar a ideia da necessidade de conter gestos e, até, de fazer aceitar a ideia de que a restrição dos contactos físicos era um dos critérios maiores da "boa-educação".

O controlo da tuberculose e da sífilis requeria, portanto, uma propaganda junto das populações, de modo a conseguir-se uma mais rápida interiorização das normas. No caso da segunda destas doenças, a par das conferências e dos artigos na imprensa diária, ou do reforço e insistência na vigilância e controlo da prostituição (actividade considerada

${ }^{(103)}$ Estêvão de Vasconcelos, "Influência do meio social no desenvolvimento da tuberculose. IV Congresso da Liga Nacional contra a tuberculose (Porto)", ibidem, XXV Anno, n 14, 7-IV-1907, p. 105.

${ }^{(104)} \mathrm{D}$. António de Lencastre, "A Tuberculose nas classes ricas", ibidem, XXV Anno, n 14, 7-IV-1907, p. 105.

(105) "Variedades. Contágios e porcarias", ibidem, XII Anno, n 32, 5-VIII-1894, p. 300.

(106) "Variedades. Liga contra o aperto de mão", ibidem, XXIII Anno, n 50, 10-XII-1905, p. 400. 
responsável pela propagação da doença - ainda que alguns médicos começassem a contestar a sua regulamentação-), também se procedeu à distribuição gratuita de postais ${ }^{(107)}$ com o intuito de, através da imagem, difundir preceitos higienistas, mas igualmente com finalidades morais. Aí se divulgavam os cuidados a ter na higiene pessoal e acentuavam-se as medidas para prevenir o contágio: os excessos na bebida e comida eram condenados, e o casamento desaconselhado, sob pena de contagiar a mulher e procriar filhos "idiotas, aleijados e tarados". Os perigos do casamento com tuberculosos, sifilíticos, epilépticos e loucos, ou, até, com alguém em cuja família houvesse tais antecedentes constituíam motivo crescente de preocupação. Compreende-se. Ainda que, em Portugal, os projectos de legislação para restringir os casamentos não tenham recebido acolhimento por parte dos poderes, a degenerescência hereditária, que caucionava um eugenismo comedido, foi um dos pilares da sabedoria médica dos finais de Oitocentos.

\section{Hereditariedade e morigeração}

De um modo ou de outro, o conceito de hereditariedade, matizado ou não pela causalidade mesológica, e a crença de que toda a patologia se revelava em sinais surgem amiúde invocados para caucionar a intervenção e a autoridade do médico, em áreas tão diversas como o foram a teoria da história e das nacionalidades, o lugar da mulher - que o incipiente movimento feminista português começava a questionar - a criminalidade, a prostituição ou a loucura e a justificar a génese dos sentimentos religiosos, ou mesmo as opções estéticas das vanguardas (o simbolismo, por exemplo).

\section{História e Nação}

A ideia de nação, tal como a cultura do século XIX a vinha construindo, ainda que pudesse aceitar, à maneira de Renan (1882), a vontade colectiva, permanentemente plebiscitada, como elemento importante,

(107) A Cartilha do sifilítico, colecção de 10 postais, Edição do Dispensário de Higiene Social de Lisboa, s.d. 
foi sensível aos argumentos étnico-históricos. Não surpreende, por isso, que também o pensamento médico, crente de que tudo era assunto seu, tenha procurado justificar a existência da nação portuguesa. E, em época em que os receios do perigo espanhol continuavam latentes, a antropometria poderia ajudar a responder a este desiderato. Assim, Gonçalves Lopes, em dissertação inaugural apresentada à Escola Médico-Cirúrgica de Lisboa em 1900, procurava explicar a emergência e a independência de Portugal à luz da especificidade antropométrica dos beirões, não questionando a ideia, corrente em finais do século XIX, e divulgada por uma certa historiografia e pelos estudos etnográficos finisseculares, de que os habitantes das Beiras seriam os descendentes directos, se não dos Lusitanos, pelo menos dos luso-romanos. Onovo médico teria encontrado uma "enorme diferença de raça" entre os beirões e os habitantes fronteiriços espanhóis, o que, no seu entender, justificava a independência de Portugal ${ }^{(108)}$. A história, a língua e a etnografia mais não seriam do que outros sinais que confirmavam os dados da natureza originária dos nossos avoengos. Ficava por explicar como é que essa natureza independente e enérgica se tinha adulterado e era agora pasto de degenerescência.

Assim, o lugar de Portugal na civilização contemporânea explicava-se, sobretudo, por condições mesológicas particulares. Não que a raça portuguesa fosse intelectualmente menos dotada do que as outras, ou, se o era nos finais do século XIX, esse atraso intrínseco tinha resultado de uma falta de estímulo secular, e não de uma falha original. Como Bombarda explicava, "por mais que seja maravilhosamente construída uma máquina acabará por se inutilizar se é posta ao abandono. [...] Pois o mesmo [se passa] com a máquina cerebral. Se a sua função se realiza vagarosamente, se não há condições que despertem a sua actividade, se as condições esporeadoras do meio são nulas ou insignificantes, a intelectualidade acabará por se amornar numa quietação de bem aventurança e o cérebro deixará de produzir aquilo que há o direito de se lhe exigir. [...] Mas essa qualidade diferente do órgão cerebral segundo as raças não é evidentemente um produto originário, mas uma consequência exacta da maior ou menor actividade do pensamento,

${ }^{(108)}$ A. Gonçalves Lopes, Os Beirões. Estudo anthropologico. Dissertação inaugural apresentada à Escola Medico-Cirurgica de Lisboa, Lisboa, Livraria e Typographia de F. Silva, 1900, p. 39. 
estabelecida desde séculos e transmitida através de inúmeras gerações"(109). Consequentemente, $o$ atraso português não podia ser visto como um sintoma de decadência irreversível, pois tal diagnóstico presumia a existência de uma grandeza anterior.

Todavia, o professor da Escola Médico-Cirúrgica de Lisboa entendia que as contribuições do nosso país para a história universal não teriam resultado de uma superioridade intelectual colectiva, "pela extensão de uma civilização", mas sim de um "rasgo de aventura", uma fulguração sem consistência ou consequência. Deste modo, preferia entender Portugal como um país ainda "na menoridade, que vê os seus irmãos adiantados em talento e em saber e que só arrastadamente, por efeito de uma indolência nativa, procura caminhar na peugada dos que vão na sua frente"(110). Mas, como resposta ao decadentismo desesperançado, corrente nos finais do século XIX, Miguel Bombarda contrapunha, em 1898 (ano em que se celebrava o IV Centenário da chegada à Índia), uma teoria que permitia sonhar com um futuro novo, desde que fossem dadas condições apropriadas à ciência - em particular à biologia - e ao médico, seu superior intérprete, na regeneração do povo português. Que a tarefa era exequível Miguel Bombarda não duvidava e, em 1905, invocava o exemplo da guerra russo-japonesa como prova do que há longos anos defendia. Pois aquela raça, "tão longamente havida como uma raça inferior", não tinha sabido arrancar-se à sua inferioridade, "o homem inferior que por tantos séculos foi desprezado, com a sua pele tisnada e com os seus costumes ridículos, com as sua fealdade e o seu nanismo"(111) não tinha vencido o Ocidente?

O optimismo do argumento continuava a ser pertinente em 1914, ainda que a situação internacional parecesse estar a abalar, pela primeira vez, a fé na Ciência, ou pelo menos a impor-lhe limites éticos. Assim, podia-se esperar a vitória dos povos latinos (ainda que coadjuvados pelos anglo-saxões) e entendia-se a superioridade da "raça" germânica como o resultado de uma perversa manipulação da natureza permitida pela ciência. Como o Presidente da Sociedade das Ciências Médicas de Lisboa

(109) Miguel Bombarda, "Civilisação portuguesa II", A Medicina Contemporanea..., XVI Anno, n 36, 4-IX-1898, p. 290.

(110) Idem, "Civilisação portuguesa IV", ibidem, XVI Anno, n 39, 25-IX-1898, p. 317.

(111) Idem, "Raças e meios", ibidem, XXIII Anno, n² 25, 18-VI-1905, p. 193. 
lembrava em 1914, os alemães tinham começado a comportar-se como "povo eleito, não pela directa revelação divina, mas pela revelação antropológica. Deus não se lhe fez ouvir pelo trovão do Sinai, mas pela voz demonstrativa da ciência. [...] Uma sociotécnica se buscou erigir como corolário prático; há que multiplicar o germano, dar-lhe terra e meios de vida [...] desapossando e aniquilando o não-germano. Aquele será apurado sistematicamente por todos os métodos de selecção positiva e negativa, pela eugénica da casta e pelo engeitamento espartano dos degenerados" ${ }^{\prime \prime 122)}$. E continuava, afirmando que desta teutomania, verdadeira patologia colectiva, engendrada na perversão científica, nascera a vontade e a justificação da guerra. Era imperioso, pois, separar a ciência pura do seu aproveitamento político e compreender que, do ponto de vista da primeira, a superioridade de uma natureza germânica não era sustentável. Se a superioridade cultural e o avanço tecnológico da Alemanha pareciam inquestionáveis, Ricardo Jorge não duvidava que tal se devia a condições políticas, sociais e económicas, premissas que não podiam legitimar nem a aventura guerreira, nem caucionar argumentos que postulassem privilégios escudados em argumentos naturalistas.

\section{Medicina e feminismo}

A importância dada à mesologia não significava, de modo nenhum, minimizar o papel dos factores naturais. Pelo contrário. Só uma leitura correcta e o respeito pela natureza permitiriam uma reorganização efectiva da sociedade. Deste modo, para o pensamento médico finissecular, o lugar da mulher na sociedade devia ter em conta a sua natureza biológica. Não cabe aqui uma análise detalhada de tudo o que, nos finais do século XIX, a medicina e a antropologia, sua ciência auxiliar, pensaram e disseram sobre a mulher ${ }^{(113)}$. Importa, tão só, sublinhar que, sem grandes discordâncias, se entendeu que os ensinamentos da ciência possibilitavam

${ }^{(112)}$ Ricardo Jorge, "A Guerra e o pensamento medico. Discurso lido na Sessão inaugural da Sociedade de Sciencias Medicas", ibidem, XXXII Anno, $\mathrm{n}^{\circ}$ 50, 13-XII-1914, p. 401.

(113) A construção médica da normalidade feminina encontra-se delineada em Maria Rita Lino Garnel, "A Loucura da prostituição", Themis. Revista da Faculdade de Direito da UNL, Ano III, n 5, 2002, pp. 139-158. 
que a medicina solucionasse a questão feminista ${ }^{(114)}$, reforçando-se, assim, com velhos argumentos vestidos de novo ${ }^{(115)}$, o lugar tradicional da mulher.

As fraquezas e debilidades da mulher não eram entendidas como a consequência de um longo processo de menorização imposta, mas como o resultado de uma fatalidade natural. Por conseguinte, não surpreende que, nas páginas da Medicina Contemporânea, se afirmasse que "todas [...] as considerações conduzem a esta verificação que o único e exclusivo papel da mulher na humanidade é a maternidade. [...] É a sua função biológica e social"(116). Menos inteligente, raciocinando defeituosamente, com menor poder criador - não se conheciam grandes músicas ou pintoras, e, mesmo em campos tradicionalmente seus, a culinária ou a moda, os criadores eram do sexo masculino -, o papel social da mulher tinha de ser necessária e exclusivamente aquele que a natureza lhe ditara. As diferenças intelectuais entre os dois sexos não permitiriam qualquer dúvida: a inteligência seria atributo masculino e o sentimento característica feminina.

Como se vê, a ciência, ou melhor, uma certa interpretação da ciência, podia conduzir a soluções contraditórias: justificar a mudança apelando à causalidade mesológica, ou, pelo contrário, invocar o determinismo da natureza para legitimar a manutenção do status quo. E não é que as diferenças fossem resultado de pensamentos e autores divergentes. Mesmo Miguel Bombarda, tão crente nas possibilidades de emancipação da "raça portuguesa", parecia restringir qualquer avanço do povo português ao sexo masculino. O próprio facto de os homens se verem obrigados a pensar a educação da mulher, de modo a moldá-la num sentido mais conforme às necessidades sociais, parecia comprovar a menoridade inultrapassável da mulher e a "inanidade de todo o movimento feminino. A mulher é a eterna submetida"(117).

(114) Jaime Almeida, A Questão feminista, Porto, Livraria Portugueza Editora, 1909, p. 22.

(115) Para estes argumentos veja-se, Nancy Tuana, The Less noble sex. Scientific, religious and philosophical conceptions of women's nature, Indiana, Indiana University Press, 1993.

(116) "Curiosidades Medicas. A inferioridade da mulher", A Medicina Contemporanea..., XVIII Anno, 29-VII-1900, p. 248.

${ }^{(117)}$ Miguel Bombarda, "Casa de boneca", ibidem, XVII Anno, n 14, 2-IV-1899, pp. 109-110. 
Ora, se o optimismo subjacente à ênfase na determinante mesológica permitia aceitar que, a longo prazo, os atrasos do povo português viessem a ser corrigidos, no imediato, alguns desequilibrios sociais - em particular, a prostituição ${ }^{(118)}$, a criminalidade e a loucura-exigiam medidas prontas. Só que estas deviam ser tomadas, tendo em conta os dados da ciência, e esta patologizava grande parte desses comportamentos.

\section{A patologização do criminoso e do louco}

É que nem todas as doenças eram contagiosas ou podiam ser curadas com uma profilaxia adequada. O depauperamento da raça, que se temia progressivo, tinha também de sopesar uma vasta gama de males "que perseguem a humanidade e que, cerrados a todo o remédio como a prevenção, constituem pela maior parte o cancro que mais fundamente a corrói". E, num século em que "a propósito do cérebro já não [era] permitido fazer poesia"(119) e em que se acreditava estarem desvendados boa parte dos mecanismos das patologias mentais, também o tratamento adequado destes doentes se tornava peça imprescindível da reorganização social. É que o juízo sobre o que afectava negativamente a sociedade não podia ser da responsabilidade única do Direito. Se à lei competia distinguir entre o que era lícito ou ilícito baseada no dano à sociedade, cabia ao médico apurar se o acto ou o comportamento tinham uma causa patológica e, portanto, evitar uma punição onde deveria haver cuidados médicos $^{(120)}$. Como atrás ficou dito, a competição pela propriedade dos problemas será um dos pontos de maior friç̧ão entre a Medicina, e particularmente, entre a Medicina Legal e o Direito.

Acreditando que todo o estado patológico teria correspondência na fisiologia também se aceitava que o que separava o normal do patológico era sobretudo uma diferença quantitativa e não qualitativa ${ }^{(121)}$; assim, certas características físicas ou certos comportamentos eram tido como

${ }^{(118)}$ Sobre a patologização da prostituta, veja-se Maria Rita Lino Garnel, art. cit., Themis..., pp. 139-158.

${ }^{(119)}$ Miguel Bombarda, "Charcot", ibidem, XI Anno, n 35, 27-VIII-1893, p. 273.

(120) Idem, "Hospital de Rilhafoles. Curso de Psychiatria. Lições sobre a epilepsia e as pseudo-epilepsias", ibidem, XIII Anno, n³, 20-I-1895, p. 18.

${ }^{(121)}$ Georges Canguilhem, Le Normal et le pathologique, Paris, P.U.F., 1972, p. 25. 
anormais, dividindo-se as opiniões nas causas que os determinavam. Se alguns, como Júlio de Matos, sob a influência do pensamento de Darwin e Spencer, perfilhavam um determinismo absoluto, isto é, a natureza produziria alguns erros que se perpetuavam na descendência, marcando indelevelmente os seus portadores com estigmas físicos, mentais ou morais (seres que inexplicavelmente teriam escapado à selecção natural), outros, como Miguel Bombarda, e por influência da sociologia francesa e da releitura das teorias darwinistas, tenderão a matizar o determinismo dos caracteres adquiridos, enfatizando, antes, os factores mesológicos, físicos e sociais.

Por isso, havia que distinguir o criminoso que praticava o ilícito na posse das suas faculdades físicas e mentais e sem qualquer hereditariedade explicativa, daquele que fazia perigar a sociedade determinado por uma natureza defeituosa, ainda que esta pudesse resultar de condições mesológicas. Aceitava-se que a exclusão devesse ser imposta a uns e a outros, mas a prisão ou o hospital de alienados eram destinos muito diferentes ${ }^{(122)}$. Factores como a epilepsia, o alcoolismo, a tuberculose, a sífilis, hereditários ou não, são crescentemente invocados como explicações científicas do acto criminoso, embora o médico estivesse consciente das dificuldades em destrinçar os dois campos ${ }^{(123)}$. Todavia, torna-se corrente, por exemplo, a afirmação da irresponsabilidade criminal dos epilépticos, por possuírem uma defeituosa construção cerebral $^{(124)}$ ou pretendem-se explicativos argumentos como os seguintes: "a mulher do réu conta que ele tem uma irmã aleijadinha das mãos e dos pés e um tio, que ao parecer era doido; [...] A mãe era muito doente. Um irmão que tem é inteiramente são. De antecedentes pessoais [o réu possui] hábitos alcoólicos"(125).

Se a medicina ajudou a distinguir o louco irresponsável do criminoso que devia ser punido, também emprestou o seu saber antropométrico à identificação criminal. Recorde-se a institucionalização dos Postos

${ }^{(122)}$ Miguel Bombarda, "Loucos e criminosos", A Medicina Contemporanea..., XXI Anno, n 28, 12-VII-1903, p. 221.

(123) Idem, "Formulas sociaes", ibidem, XXI Anno, n 37, 13-IX-1903, p. 294.

${ }^{(124)}$ Miguel Bombarda e Caetano Beirão, "Relatórios e Consultas Medico-Legaes. Epilepsia. Agressões", ibidem, XV Anno, 25-IV-1897, p. 133.

(125) Idem, "Relatorios e consultas medico-legaes. Exame de um incendiário", ibidem, XIV Anno, n² 23, 7-VI-1896, p. 177. 
Antropométricos de Lisboa e Porto, criados em 1898, e a funcionar desde os inícios do século junto da cadeia da Relação do Porto e do edifício do Juízo de Instrução Criminal de Lisboa(126). Neste último local, sob a orientação do médico Francisco Ferraz de Macedo, fotografavam-se os detidos, mediam-se os crânios e registavam-se as relevantes informações antropométricas, isto é, aí se procuravam os estigmas que confirmavam a predisposição para a violência e para o crime. E se o determinismo da antropologia criminal de Lombroso começava a ser questionado, continuou a acreditar-se que a natureza deixava nos corpos, e em particular na cabeça e face, indícios predisponentes e preparativos de actos criminais ${ }^{(127)}$, ainda que uma correcta leitura destes tivesse de ser acompanhada por informações sobre a "origem dos ascendentes, das penetrações havidas na família, da raça madre do povo a que pertencem ou da origem histórica do povo a que se filiam"(128).

\section{Patologias políticas e culturais}

Tendo em conta o que temos vindo a expor, surge como lógico o empenhamento, por vezes militante, de alguns médicos no combate político, em particular na fundamentação "científica" de uma mudança de regime, ou na denúncia das chamadas "monomanias" religiosas.

Se é verdade que alguns clínicos permaneceram fiéis à Monarquia, mesmo após a implantação da República - caso do professor e director da Morgue de Lisboa, Azevedo Neves - inúmeros foram os artigos escritos com pretensões científicas, que apresentaram as famílias reais como exemplos de degenerescência hereditária. A família real portuguesa não era, naturalmente, excepção ${ }^{(129)}$. Frutos de uma degenerescência

(126) "Variedades. Serviço de Anthropometria de Lisboa", ibidem, XIX Anno, no 14, 7-IV-1901, p. 116.

${ }^{(127)}$ Mendes Correia, "Registo. A Luta contra o crime", Movimento Medico. Revista quinzenal de Medicina e cirurgia, VIII Anno, nº 6, 15-III-1912, p. 94.

${ }^{(128)}$ Francisco Ferraz de Macedo, "Estigmas e o melindre em os valorisar", in Galeria dos Criminosos Celebres, vol. III, Lisboa, 1898, p. 16.

${ }^{(129)}$ A título de exemplo veja-se A. Aurélio da Costa Ferreira, "Caveiras de princesa. D. Maria Francisca de Sabóia e sua filha D. Isabel", Movimento Medico..., VIII Anno, 15-V-1912, pp. 147-149. 
continuada, propiciada pelos casamentos consanguíneos e por uma educação pervertida, os reis, as suas mulheres e os seus filhos eram gente inferior, patológica mesma, sujeitos a estados de obsessão ou de loucura religiosa e nada poderia justificar o lugar preeminente que ainda detinham ${ }^{(130)}$. Nos anos iniciais da República, continuou-se a sustentar a anormalidade patológica da família real, resposta médica aos que ainda sonhavam com o regresso à Monarquia. Júlio Dantas, por exemplo, em comunicação à Academia das Ciências de Lisboa, em 1913, dissertou sobre a sífilis de D. João II e sobre a de D. José, acentuando a influência desta doença sobre "as raças reais portuguesas"(1311).

Se a escolha do regime republicano podia ser apresentada como uma ilação lógica decorrente da degenerescência das famílias reais, bem como o regime mais adequado à natural evolução das sociedades civilizadas, o combate contra outras opções políticas de vanguarda também foi problema médico. Recordem-se as posições de Júlio de Matos sobre o socialismo ${ }^{(132)}$. Para o ilustre alienista, a ênfase na soberania popular e o culto da igualdade, tal como eram postuladas pela doutrina socialista $\mathrm{e}$ propagandeadas pelos seus apóstolos, eram, afinal, indícios de patologia. É que uma doutrina apostada na construção da sociedade igualitária e niveladora contrariava o caminho evolutivo em direcção à heterogeneidade crescente, percurso natural demonstrado pela doutrina spenceriana. Acreditar na "superstição socialista" e no fim da história que ela prometia seria escolher o caminho do retrocesso e comprometer o futuro da humanidade. Lutar, acreditar e desejar que a humanidade regressasse a um estádio pré-civilizacional, a um tempo sem propriedade, sem familia e sem indivíduo seriam desejos regressivos, que só podiam convir a quem guardava, atavicamente, as marcas da degenerescência.

No combate pela regeneração da sociedade, e como última nota, não pode deixar de se apontar a assunção de posições secularizadoras por este grupo profissional. Na verdade, alguns médicos foram combaten-

${ }^{(130)}$ Dr. Antão de Mello, A Imbecilidade e a degenerescencia nas familias reaes, Lisboa, Livraria Central de Gomes de Carvalho, 1908.

${ }^{(131)}$ Sessão pública da Academia das Sciências de Lisboa, em 7 de Dezembro de 1913, Lisboa, Imprensa Nacional, 1913, p. 20.

${ }^{(132)}$ A este propósito veja-se, por todos, Ana Leonor Pereira, Darwin em Portugal (1865-1914). Filosofia, História, Engenharia Social, Coimbra, Livraria Almedina, 2001, pp. 370-380. 
tes anticlericais e procuraram fundamentar, cientificamente, o seu anticlericalismo ou mesmo o seu ateísmo. Para Miguel Bombarda, por exemplo, "a ciência é incompatível com a crença. A ciência é incompatível com a religião"(133). E Júlio de Matos, ao pronunciar-se pela insanidade mental de Rosa Calmon, em 1900(134), fundamentava o seu diagnóstico não só na pesada hereditariedade familiar e em estigmas físicos, mas, sobretudo, nos excessos de religiosidade e na vontade teimosa em tomar ordens. E os religiosos, em particular os jesuítas, pela sua acção nefasta, só poderiam ser entendidos como seres degenerados, seres que fugiam da luz "para se embrenharem pelas sombras de místicas crendices", apenas apropriadas a inteligências impreparadas ou constitucionalmente débeis como as das mulheres. A força do pensamento médico era já tal que, como se sabe, no seguimento do 5 de Outubro, o Posto Antropométrico de Lisboa fotografou e avaliou alguns jesuítas procurando estabelecer a correlação entre as medidas antropométricas e demais estigmas degenerativos e a opção religiosa pela Sociedade de Jesus.

A apreciação dos fenómenos estéticos também não escapou ao olhar cientista do médico, ávido de encontrar sintomas de anormalidade e de patologia, e de pautar as regras dos comportamentos sociais, tidos como normais. Júlio Dantas, por exemplo, na sua dissertação inaugural, apresentada à Escola Médico-Cirúrgica de Lisboa em $1900^{(135)}$, defenderá a ideia de que a loucura e a decadência não se encontravam apenas no manicómio. Pelo contrário. Seguindo a interpretação de Max Nordau que não cita mas certamente conhece -, entende que a obra da maior parte dos poetas e pintores do seu tempo seriam sintomas de perturbação mental. Assim, os receios de uma degenerescência a permear o tecido social eram reforçados, e Dantas concluía pelo papel fundamental do médico, também na orientação artística da nação. Mais do que qualquer outro intelectual, só o médico, maître a penser por excelência, por uma formação adequada à etapa científico-técnica em que a humanidade teria

${ }^{(133)}$ Miguel Bombarda, "A escravatura infantil", A Medicina Contemporanea..., XXII Anno, n 5, 29-I-1905, p. 33.

(134) Júlio de Mattos, A Questão Calmon. Reflexões sobre um caso medico-legal, Porto, Livraria Chardron, 1900.

(135) Júlio Dantas, Pintores e poetas de Rilhafoles, Lisboa, Livraria Editora Guimarães, Libanio \& Cia, 1900. 
entrado, poderia diagnosticar o atavismo ou a paranóia reveladas pela arte e pela literatura, que longe de deslumbrarem, deveriam estigmatizar socialmente os autores e o seu público, merecedores, afinal, de tratamento psiquiátrico.

Como se vê, pelo que apenas se esboçou, a medicina a partir da sua vocação clínica, insistia que também era tarefa sua iluminar a regeneração social. Por isso, buscou impor a sua autoridade, enfatizando o valor da ciência, a todos os aspectos individuais ou colectivos, físico-mentais, sociais e morais. Pelo que não será abusivo considerá-la como a versão mais totalizadora (e utópica) do cientismo.

\section{Conclusão}

Ao longo das últimas décadas do século XIX e primeiras décadas do século $X X$, os médicos conseguiram impor largamente a sua visão do mundo. E se a voz das elites médicas colhia audiência, com maior ou menor dificuldade e luta, junto das outras elites, é ao trabalho de vulgarização e à pedagogia higienista feitos pelos clínicos anónimos, no hospital, nos consultórios e nas visitas domiciliárias, que se deveu a transformação dos comportamentos e a nova disciplina dos corpos. Ao longo do século $\mathrm{XIX}$ e inícios do século $\mathrm{XX}$, os médicos construíram um poder, tanto maior quanto mais conseguiram que a sua voz fosse ouvida pelas instâncias do Estado e que a modificação dos comportamentos fossem interiorizadas pelas populações.

Neste processo, os médicos afirmaram-se como profissionais liberais, para efeitos de honorários e/ou contribuições e na defesa dos seus interesses corporativos, passo importante e decisivo na afirmação do grupo como elite intelectual. Mas não deixaram de permitir e até incentivar a sacralização da medicina e daqueles que a escolhiam.

O caso de Sousa Martins é exemplar. Objecto de culto popular ${ }^{(136)}$ desde o momento da sua morte, os seus colegas longe de o desencorajar, logo perceberam que este também servia as estratégias médicas. Como diria Ricardo Jorge, "a imortalidade não é apenas a relíquia do valor

(136) José Machado Pais, Sousa Martins e suas memórias sociais. Sociologia de uma crença popular, Lisboa, Gradiva, 1994. 
pessoal do extinto; sem o culto póstumo, sem o fervor dos adeptos, não há peanha que a carcoma do tempo não derrube prestes"(137). A consolidação do poder médico - à semelhança do que outros grupos iam fazendo ${ }^{(138)}$ - exigia a construção sacralizadora da memória dos heróis da medicina, "hoje nossos oragos profanos [...] aqueles que mais alto professaram a religião da medicina, a religião da sua ciência, a religião da sua caridade"(139). Ou, como se afirmava em artigo de vulgarização, "se combater o sofrimento é obra que pode qualificar-se de divina que diremos da que se propõe evitá-la? [...] Pela natureza mesmo do seu ministério o médico não é, não pode ser um simples mercenário; ele passa espalhando o bem [...] Para ele não há noite, nem chuva, nem frio, porque as suas horas de trabalho são aquelas que a dor lhes marca"(140). Quer isto dizer que os médicos, desde os inícios do século XIX, souberam compreender que se esperava deles um comportamento semelhante ao dos sacerdotes ${ }^{(141)}$, e que isso servia bem os seus interesses.

Distinto pelo traje que envergava no hospital e no consultório, pelo sigilo a que estava obrigado - elemento de sacralidade que partilhava com o padre e com o poder judicial - e sobretudo pela linguagem hermética, só passível de ser entendida pelos inciados, ou ainda pelos exames científicos que realizava (exames misteriosos para os doentes), o médico assumia-se e fazia-se aceitar como intérprete único dos signos que permitiam avaliar e distinguir o normal e o patológico, o inocente e o culpado, o são e o louco. E este saber científico, que apenas eles detinham, permitia-lhes prometer a salvação, individual e colectiva - se ao menos a sua voz continuasse a ser ouvida.

${ }^{(137)}$ Ricardo Jorge, Souza Martins. Discurso proferido na Sociedade de Medicina e Cirurgia na sessão de 8-II-1897, Porto, Typ. A vapor de Arthur José de Sousa \& Irmão, 1897, p. 8.

(138) Fernando Catroga, O Céu da memória. Cemitério romântico e culto cívico dos mortos (1765-1911), Coimbra, Minerva, 1999, pp. 171-206.

(139) Ricardo Jorge, ob. cit., p. 29.

${ }^{(140)}$ A. Dias Chorão, "O papel social do médico", Brotéria, vols. X-XIII, (série vulgarização científica), 1912-1914, p. 351 e 355.

(141) Jorge Crespo, História do corpo, Lisboa, Difel, 1990, pp. 103-104. 